Vivek Ghosal *

\title{
Endemic Volatility of Firms and Establishments: Are Real Options Effects Important?
}

* Georgia Institute of Technology

SP II $2003-13$

September 2003

ISSN Nr. $0722-6748$

Research Area

Markets and Political Economy

Research Unit

Competitiveness and Industrial Change
Forschungsschwerpunkt

Markt und politische Ökonomie

Abteilung

Wettbewerbsfähigkeit und industrieller Wandel 
Zitierweise/Citation:

Vivek Ghosal, Endemic Volatility of Firms and Establishments: Are Real Options Effects Important?, Discussion Paper SP || 2003 - 13, Wissenschaftszentrum Berlin, 2003.

Wissenschaftszentrum Berlin für Sozialforschung $\mathrm{gGmbH}$, Reichpietschufer 50, 10785 Berlin, Germany, Tel. (030) 25491 - 0 Internet: www.wz-berlin.de 


\section{ABSTRACT \\ Endemic Volatility of Firms and Establishments: Are Real Options Effects Important?}

by Vivek Ghosal ${ }^{1}$

Consider the intertemporal volatility of the number of firms and establishments within an industry over a relatively long span of time. Data from the U.S. manufacturing sector shows that this degree of endemic volatility varies widely across industries. Examining the determinants of this volatility is important in its own right as it reflects on the underlying forces governing entry and exit. In addition, data shows that the volatility of firms and establishments is significantly correlated with the volatility of the number of production and nonproduction workers employed in an industry. The primary focus of this paper is to evaluate the role played by the real options channel which suggests that sunk costs and uncertainty may be important determinants of the degree of volatility of the number of firms. We also control for other factors related to advertisingintensity, industry growth and technological change. An advantage of the manufacturing industry dataset we use in this study is that it combines the annual timeseries data from the Annual Survey of Manufactures with data from the five-yearly Census of Manufactures. This allows us to construct measures of uncertainty about profits, sunk capital costs, technological change, among others. Our key findings are: (1) industries with higher sunk capital costs and profit uncertainty have significantly lower endemic volatility of the number of firms and establishments; and (2) these relationships are non-linear as suggested by theory with even small amounts of sunk costs or profit uncertainty contributing to significantly lower firm volatility. Our findings appear broadly consistent with the predictions of the real options channel. We highlight some implications of our findings for antitrust/competition policy and labor market dynamics.

Keywords: Firm and establishment volatility; sunk capital costs; profit uncertainty; technological change; antitrust/competition policy; employment dynamics.

JEL Classification: L11, L40.

1 For helpful comments and discussions on related versions of this paper, I thank audiences at: International Industrial Organization Conference (Boston); "The Economics of Entrepreneurship and the Demography of Firms and Industries" organized by Zentrum für Europäische Wirtschaftsforschung, Mannheim; and "PostEntry Performance of Firms: Role of Technology, Growth and Survival" organized by the University of Bologna. This paper was completed when I was a research visitor at CESifo (Munich) and Wissenschaftszentrum Berlin für Sozialforschung (WZB) during summer 2003; I thank them for their research support and hospitality. 


\section{Endemische Volatilität von Unternehmen und die Bedeutung von ,real option effects'}

Betrachtet man die intertemporale Schwankung der Anzahl von Unternehmen eines Industriezweigs über einen relativ langen Zeitraum, so zeigen Daten der U.S.amerikanischen verarbeitenden Industrie eine große Variation des Grades dieser endemischen Schwankungen zwischen unterschiedlichen Industriezweigen. Die Untersuchung der Determinanten dieser Volatilität ist für sich genommen bedeutsam, indem sie die Hintergründe für den Markteintritt und austritt von Firmen beleuchtet. Darüber hinaus lässt sich eine hohe Korrelation zwischen der Schwankung in der Anzahl der Unternehmen und der Volatilität der Zahl der Arbeiter, die in der Produktion und in nicht-produzierenden Tätigkeiten beschäftigt sind, herstellen. Das Hauptaugenmerk dieses Papier ist es zu bewerten, welche Rolle der ,real options'- Kanal spielt, was impliziert, dass ,sunk costs' und Unsicherheit entscheidende Bestimmungsfaktoren für den Grad an Volatilität der Unternehmenszahl sind. Bei der Untersuchung werden auch andere Faktoren, die mit Werbungsintensität, Industriewachstum und technologischem Wandel verbunden sind, kontrolliert. Ein Vorteil des in der Analyse verwandten Datensatzes liegt darin, dass er jährliche Zeitreihendaten aus dem Jahresbericht des verarbeitenden Gewerbes der U.S.A. (Annual Survey of Manufacturers) mit Daten des Zensus des verarbeitenden Gewerbes, der fünfmal im Jahr erhoben wird, kombiniert. Das gestattet die Konstruktion von Maßzahlen zur Unsicherheit über Gewinne, versunkene Kapitalkosten, technologischen Wandel, etc.. Die Hauptergebnisse der Untersuchung sind: (1) Industriezweige mit höheren versunkenen Kapitalkosten und Gewinnunsicherheit zeichnen sich durch signifikant geringere endemische Volatilität in der Anzahl der Unternehmen aus; (2) diese Beziehungen sind nicht-linear, wie bereits die Theorie vermuten lässt, die besagt, dass schon geringe ,sunk costs' oder Gewinnunsicherheit zu bedeutend geringerer Schwankungsbreite in der Unternehmenszahl beitragen. Die Ergebnisse scheinen insgesamt mit den Aussagen zum ,real options'- Kanal übereinzustimmen. Einige Implikationen der Resultate für die ,Antitrust'- und Wettbewerbspolitik sowie Arbeitsmarkt-dynamik werden herausgestellt. 


\section{Introduction}

For a given industry, consider data on the number of firms and establishments over a relatively long span of time and use this to compute the volatility (standard deviation) of firms and establishments. This gives us a measure of the longer-run or endemic volatility for that industry. As we examine data for U.S. manufacturing sector, we find wide differences across industries in this degree of endemic volatility of firms and establishments. ${ }^{1}$ While such differences in firm volatility has been documented (Caves, 1998; Dunne, Roberts and Samuelson, 1988; and Sutton 1997.a), there is relatively little empirical work highlighting the determinants of this heterogeneity. The central question this paper seeks to shed light on is: To what extent does the real options channel help explain the observed differences in the endemic volatility of the number of firms and establishments across industries?

In recent years, the real options channel has been shown to be a key determinant of other aspects of firm and industry behavior such as investment outlays, capital adjustment and employment. ${ }^{2}$ While the theory points to sunk capital costs and uncertainty about profits as potentially important determinants of firm volatility, there is relatively little empirical work examining these predictions in the context of firm volatility. The two pillars of the real options channel are sunk capital costs and uncertainty. Sunk capital costs act as a barrier to entry and this is expected to lower entry and, consequently, exits, resulting in lower variability of the number of firms. It is well established that greater uncertainty about profits raises (lowers) the entry (exit) trigger price, implying that industries with greater uncertainty may be subject to less entry and exit, resulting in reduced firm volatility. Finally, uncertainty in conjunction with sunk costs exacerbate these effects. In sections 2.1 and 2.2 we review the theoretical insights. In section 2.3 we examine additional factors that may affect firm volatility such as advertising-intensity,

\footnotetext{
${ }^{1}$ While we describe the data later, Table 1 (rows 1 and 2), using data on 266 U.S. manufacturing industries over the seven Census years 1963-1992, presents summary statistics documenting the wide differences in the volatility (standard deviation) of the number of firms and establishments across industries.

${ }^{2}$ See Lensink, Bo and Sterken (2002) for an excellent review of the theory and empirical findings. Also see Driver and Whelan (2001) and Driver et. al. (2002) for alternate issues and methodologies related to investment outlays. Rosenberg (2002) finds interesting links to labor demand and input choices in general.
} 
industry long-run growth and technological change. ${ }^{3}$

Our empirical model is presented in section 3 and the details about data and measurement of sunk costs, uncertainty, technology, and other variables are presented in Section 4 . The estimation results are presented in section 5. Our empirical findings reveal that greater sunk costs and uncertainty significantly lower the volatility of the number of firms and establishments within an industry. The theory (Section 2) suggests that even small amounts of sunk costs or uncertainty are sufficient to induce a high degree of entry/exit hysteresis and reduce firm volatility, and subsequent increases in these variables have progressively diminishing effects. We find evidence in favor of such non-linear relationships. Of the other variables we consider, we find that technology effects as captured by industry R\&D intensity contributes to lower volatility of the number of firms and establishments.

Our findings on sunk costs and uncertainty can be useful for research in several areas. In Section 7 we comment on the implications of our findings for the analysis of competitive effects and entry conditions in antitrust/competition policy, with particular reference to horizontal mergers. We also note some implications for labor markets. Our data shows that the cross-industry correlation between the standard deviation of the number of firms and the standard deviation of production workers is about 0.25 ; the corresponding correlations are 0.42 for non-production workers and 0.32 for total employment. The correlations are statistically significant and economically meaningful, implying that turnover of firms play a key role in determining labor market volatility. Thus examining the determinants of firm volatility sheds useful light on the functioning of labor markets with implications for search models, job creation and entrepreneurship.

\footnotetext{
${ }^{3}$ In this paper we examine the determinants of longer-run, or endemic, volatility of firms and establishments. Ghosal (2002) examines the shorter-run time-series fluctuations in uncertainty and industry structure. Given our objective of examining longer-run cross-industry differences, we do not focus on models of learning and the intertemporal evolution of firms and industries (e.g., Jovanovic, 1982; Pakes and Ericsson, 1998).
} 


\section{Theoretical Considerations}

\subsection{Sunk Capital Costs}

For the $\mathrm{i}^{\text {th }}$ industry, let $\mathbf{K}$ be the entry capital requirement, $\mathbf{r}$ the unit price of new capital, and $\phi$ the resale/scrap price of this capital with $r>\phi$. A firm contemplating entry into this industry must take into consideration the non-recoverable component of entry investment $\Phi=(\mathrm{r}-\phi) \mathrm{K}$, the sunk cost ${ }^{4}$ Given that characteristics of technology and capital vary considerably industries, a priori one expects wide crossindustry variation in $\Phi$. Sunk entry capital costs act as a barrier to entry and mobility. This notion has been used to understand firms' entry and exit decisions (e.g., Baumol, Panzar and Willig, 1982; Caves and Porter, 1977; Dixit, 1989; Dixit and Pindyck, 1994) and investment behavior (e.g., Dixit, 1980; Dixit and Pindyck, 1994; Spence, 1977). ${ }^{5}$ The key results that emerge from this literature are: (1) when $\Phi$ is high, entry will be lower and, consequently, exits will also be lower implying that the variance of firms is likely to be lower; and (2) numerical simulations in Dixit (1989, Fig.2) show that, starting with zero $\Phi$, even a small increase in $\Phi$ induces significant entry/exit hysteresis and subsequent increases in $\Phi$ have a proportionately lesser effect, implying a non-linear relationship. ${ }^{6}$ Thus, if $\sigma(\text { FIRMS })_{\mathbf{i}}$ measures the volatility (say, standard deviation) of the number of firms for the $\mathrm{i}^{\text {th }}$ industry, then $\sigma(\mathrm{FIRMS})_{\mathrm{i}}=\mathrm{g}(\Phi)_{\mathrm{i}}$, with $\mathrm{g}_{\Phi}<0$ and $\mathrm{g}_{\Phi, \Phi}>0$.

Empirical prediction: Industries with high sunk entry capital costs $\Phi_{\mathrm{i}}$ are expected to show lower $\sigma(\text { FIRMS })_{\mathrm{i}}$. The relationship is likely to be non-linear with initial increases in $\Phi$ showing greater decreases in $\sigma($ FIRMS).

${ }^{4}$ To simplify, we ignore depreciation. Sunk costs will be relevant for the non-depreciated portion of capital.

${ }^{5}$ In the contestable markets literature, for example, sunk costs are the key determinant of entry and exit.

${ }^{6}$ The simulation results show (Dixit, 1989; Dixit and Pindyck, 1994, Ch.7,8) that the rise (fall) in the entry (exit) trigger price is substantial for initial, small, increases in sunk costs. While the entry (exit) triggers continue to rise (fall) as sunk costs rise, the rate is diminishing signifying non-linearity 


\subsection{Profit Uncertainty}

Dixit (1989) models a price-taking risk-neutral firm, with access to a given technology, that maximizes expected net present value. Let $\pi$ be a measure of profitability. ${ }^{7}$ Uncertainty is measured by the

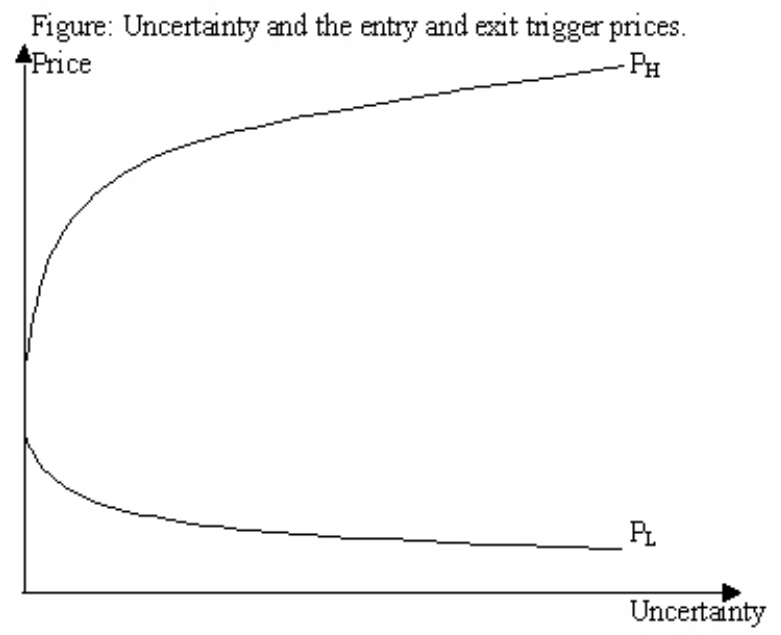
conditional standard deviation of the process generating $\pi, \sigma(\pi)$. Define a pair of entry and exit trigger prices $\mathbf{P}^{\mathrm{H}}$ and $\mathbf{P}^{\mathrm{L}}$. In the range $\left(0, \mathrm{P}^{\mathrm{H}}\right)$ the potential entrant holds on to its option to enter, and over $\left(\mathrm{P}^{\mathrm{L}}, \infty\right)$ an incumbent remains in the industry. Greater $\sigma(\pi)$ implies an option value of waiting and this raises (lowers) $\mathrm{P}^{\mathrm{H}}\left(\mathrm{P}^{\mathrm{L}}\right)$. Rise in $\mathrm{P}^{\mathrm{H}}$ lowers entry. $\mathrm{P}^{\mathrm{L}}$ falls as the firm knows it has to re-incur sunk costs upon re-entry and this delays exit. Thus greater $\sigma(\pi)$ lowers both entry and exit; induces greater hysteresis. Numerical simulations in Dixit (1989) and Dixit and Pindyck (1994, Ch.7,8) show that: (1) the entry and exit thresholds widen significantly under greater $\sigma(\pi)$; and (2) starting from zero $\sigma(\pi)$, even small increases in $\sigma(\pi)$ significantly widen the entry/exit thresholds with subsequent increases having proportionately lesser effect, implying a non-linear relationship. In short, $\sigma(\text { FIRMS })_{\mathrm{i}}=\mathrm{f}[\sigma(\pi)]_{\mathrm{i}}$, with $\mathrm{f}_{\sigma(\pi)}<0$ and $\mathrm{f}_{\sigma(\pi), \sigma(\pi)}>0$. The above figure provides an illustration (based on the numerical results in the above papers) of $\sigma(\pi)$ and price thresholds, $\mathrm{P}^{\mathrm{H}}$ and $\mathrm{P}^{\mathrm{L}}$.

Turning to imperfect competition, Dixit and Pindyck (1994, p.309-315) show that the option

\footnotetext{
${ }^{7}$ The relevant stochastic element can be couched in terms of any relevant variable such as profits, cash-flows, price, among others. Caballero and Pindyck (1996) and Dixit and Pindyck (1994) discuss uncertainty about cashflows, profits, among other variables. In the simplest settings, the models consider uncertainty about prices holding constant input costs and technology; but this term reduces to a profitability interpretation.

${ }^{8}$ In practice, we're unable to observe the threshold prices $\mathrm{P}^{\mathrm{H}}$ and $\mathrm{P}^{\mathrm{L}}$. In empirical work one typically evaluates the link between uncertainty and the variable of interest such as entry/exit or investment and make an indirect inference.
} 
value of waiting, which slows entry, remains when $\sigma(\pi)$ is greater. But an oligopolistic setting requires consideration of pre-emption by rival(s) and this may necessitate a faster response. Therefore, the net effect is ambiguous. ${ }^{9}$ The literature which examines the incentives for incumbents or first-movers in oligopolistic markets to engage in strategic pre-commitments to erect entry barriers shows that it may be optimal for the incumbent/first-mover to pre-commit (e.g., Appelbaum and Lim, 1985; Spencer and Brander, 1992). But uncertainty lowers the optimal pre-commitment due to greater uncertainty about the success of the entry-deterring strategy. Overall, oligopolistic settings highlight the ambiguity of outcomes, which are critically dependent on model assumptions.

Empirical prediction: Industries with greater $\sigma(\pi)$ should attract lower entry and, consequently, have lower exits. Thus $\sigma($ FIRMS) is expected to be lower in industries with greater $\sigma(\pi)$. The relationship is likely to be non-linear with even small amounts of $\sigma(\pi)$ producing considerable hysteresis and lower $\sigma(\mathrm{FIRMS})$, but subsequent increases in $\sigma(\pi)$ generating progressively lesser hysteresis.

\section{Interaction between Sunk Costs and Uncertainty}

The results in Dixit (1989) and Dixit and Pindyck (1994) show that uncertainty and sunk costs by themselves induce hysteresis in entry and exit. This is expected to lower the volatility of firms. In addition the results show that the effect of uncertainty, for example, is exacerbated in the presence of higher sunk costs. This suggests that the empirical model should allow for cross-dependence between uncertainty and sunk costs.

\footnotetext{
${ }^{9}$ To briefly highlight the issues, start with two potential entrants $\mathrm{F}(1)$ and $\mathrm{F}(2)$. Let $\mathrm{F}(1)$ be the leader and $\mathrm{F}(2)$ follower. Let $\mathrm{P}(1)$ be the price at which $\mathrm{F}(1)$ enters, and $\mathrm{P}(2)$ when $\mathrm{F}(2)$ enters, $\mathrm{P}(2)>\mathrm{P}(1)$; if $\mathrm{P}>\mathrm{P}(2)$ then $\mathrm{F}(2)$ enters imme diately, otherwise it waits for prices to rise above $\mathrm{P}(2)$. $\mathrm{P}(1)$ exceeds the Marshallian entry trigger due to uncertainty. Let $F(1)$ earn profits $\Pi(1)$ during the interval of its sole occupancy in the industry; when $\mathrm{P}(1)<\mathrm{P}<\mathrm{P}(2)$. $\mathrm{F}(1)$ rationally expects profits to fall when $\mathrm{F}(2)$ enters. Entry by $\mathrm{F}(2)$ will truncate the upper end of the distribution of profit flows. Thus, $\mathrm{F}(1)$ must receive a premium before it enters. Of course, in this setting there is no mechanism determining the leader/follower: this could be determined endogenously or exogenously; who enters and when depends on the underlying conditions. Now consider simultaneous decision making and $\mathrm{P}=\mathrm{P}(1)+\epsilon$ ( $\epsilon$ is small positive). Price is above the entry threshold and since neither firm wants to wait, for the fear of being preempted by its rival, and could assume leadership role, we could get simultaneous entry. In this case entry could be faster than in the leader-follower setting described above.
} 


\subsection{Other Considerations}

\section{Technological Change}

Winter (1984) hypothesizes that when the accumulated stock of technology has emanated from within the industry via learning-by-doing and other channels ("routinized" regime), outsiders (new entrants) will have a difficult time making inroads. One way to describe the effects is as follows. In an industry primarily characterized by routinized regime, the incumbents' efficiency advantage will be greater; this asymmetry will make it difficult for entrants to compete. In equilibrium, such industries will be characterized by lower entry and potentially lower exits. In contrast, when there is new firm innovation (Winter's "entrepreneurial” or non-routinized regime), new entrants are more competitive and entry is facilitated. Thus routinized regime is likely to have an entry-retarding effect whereas an entrepreneurial regime will be entry-facilitating. In other words, the "inside" versus "outside" industry streams of innovation are key to determining whether entry is facilitated or hindered. ${ }^{10}$ Sutton (1997.a; 1998) provides a review of the literature and additional insights. A general theme emerging from Audretsch's (1995) empirical results is that higher industry-wide innovation results in reduction of new startup firms and decreases the survival chances of new firms. In contrast, new firm survival rate is much higher where new firm innovation rate is higher. These findings lend support to Winter's hypotheses. Thus, the effect of technological change on $\sigma($ FIRMS) will depend on whether the innovations are emanating from outside or inside the industry. Given that both types are likely to be prevalent in the data, the net effect appears to be ambiguous.

${ }^{10}$ In our study we do not examine the predictions of the life-cycle models (e.g., Gort and Klepper, 1982; Jovanovic and MacDonald, 1994) because these models deal with the life-cycle of industries from birth to maturity. Our study is concerned with which industries have endemically greater or lower volatility in the number of firms and we use a relatively mature sample of industries. However, even in the life-cycle models, innovations that emanate from outside the industry facilitate entry and lead to significant positive net entry, while innovations that emanate from within the industry lead to rise in entry barriers (Gort and Klepper, p.634). 


\section{Additional Factors}

We consider some additional control variables that may influence $\sigma($ FIRMS). First, we control for industry advertising intensity. Greater advertising intensity may have both entry-retarding as well as entry-enhancing effects (Kessides, 1986). The former may reduce entry due to advertising related sunk cost barriers and, consequently, exits will also be lower leading to lower $\sigma$ (FIRMS). The latter implies that a greater differentiated array of products may facilitate entry into "niche" market segments. The net effect appears to be ambiguous. Second, in some secondary specifications, we include the industry's mean rate of growth over the sample period. Greater growth may result in facilitate entry (turnover) resulting in increased $\sigma($ FIRMS), but this effect is likely to be conditioned on barriers-to-entry.

\section{Empirical Model}

Let $\sigma(\text { FIRMS })_{\mathrm{i}}$ be a measure of the degree of endemic volatility of the number of firms for a given industry. Our objective is to examine differences across industries in $\sigma(\text { FIRMS })_{\mathrm{i}} \cdot{ }^{11}$ We also examine the differences across industries in the volatility of the total number of establishments $\sigma(\mathbf{E S T B S})_{\mathrm{i}}$. An establishment is defined as an economic (production) entity operating at a location; a firm can have more than one establishment. The number of establishments could increase or decrease as firms enter or exit the industry. But they could also increase (decrease) if incumbent firms expand (contract) operations, say, by entering (exiting) new (existing) geographic markets. This can be viewed as providing some complementary information about entry/exit and volatility.

The relationship that we will estimate is given by:

$$
\sigma(\mathrm{FIRMS} \text { or ESTBS })_{\mathrm{i}}=\alpha \sigma(\pi)_{\mathrm{i}}^{\beta} \Phi_{\mathrm{i}}^{\gamma} \mathrm{T}_{\mathrm{i}}^{\delta} \mathrm{AD}_{\mathrm{i}}^{\xi} \psi^{\prime} \mathbf{Z}_{\mathrm{i}} \mathrm{v}_{\mathrm{i}}
$$

\footnotetext{
${ }^{11}$ As noted in section 4, for each industry we compute the standard deviation of the (detrended) number of firms over the seven Censu s years, 1963-92. This gives us an industry-specific measure of endemic volatility, $\sigma(\mathrm{FIRMS})_{\mathrm{i}}$. In our estimated regressions, we use $\sigma(\text { FIRMS })_{\mathrm{i}}$ as the dependent variable for which we have 266 observations.
} 
where ' $\mathrm{i}$ ' indexes industry, $\sigma$ (FIRMS or ESTBS) is the standard deviation of the number of firms (or establishments), $\sigma(\pi)$ is profit uncertainty, $\Phi$ sunk capital costs, T a measure of technological progress, $\mathrm{AD}$ is advertising intensity, $\mathbf{Z}$ represents a vector of potentially other control variables (section 2.3) with $\psi$ the corresponding vector of coefficients, $v$ a random error term, and $\alpha, \beta, \gamma, \delta$ and $\psi$ are the coefficients to be estimated. In theory, the effect of $\sigma(\pi)$, for example, is (i) potentially non-linear and (ii) conditioned on $\Phi$. The above specification allows for these non-linearities and cross-dependence. From the option value channel, $\sigma(\pi)$ and $\Phi$ are expected to lead to lower firm volatility, implying $\beta<0$ and $\gamma<0$. With $\beta<0$ and $\sigma(\pi)>0$, we have $\partial \sigma($ FIRMS $) / \partial \sigma(\pi)<0$ and $\partial^{2} \sigma($ FIRMS $) / \partial \sigma(\pi)^{2}>0$. The degree of curvature will depend on the value of $\beta$. For the cross-dependence of uncertainty and sunk costs, assuming all other variables are constant and dropping industry subscripts, we simplify (1) to get $\sigma(\mathrm{FIRMS})=\omega \sigma(\pi)^{\beta} \Phi^{\gamma}$, where $\omega$ is a constant. Taking the total differential we get:

$$
\mathrm{d} \sigma(\mathrm{FIRMS})=\beta \sigma(\pi)^{\beta-1} \Phi^{\gamma} \mathrm{d} \sigma(\pi)+\gamma \sigma(\pi)^{\beta} \Phi^{\gamma-1} \mathrm{~d} \Phi+\beta \gamma \sigma(\pi)^{\beta-1} \Phi^{\gamma-1} \mathrm{~d} \sigma(\pi) \mathrm{d} \Phi,
$$

ignoring the higher-order terms. Given that $\beta, \gamma<0$ and $\sigma(\pi), \Phi>0$, the first two terms are negative and the last term positive. From our estimated equations, we evaluate both the curvature of the relationships and the extent of cross-dependence between $\sigma(\pi)$ and $\Phi$.

We estimate (1) in log-linear form (ln denotes logarithms):

$$
\ln \sigma(\mathrm{FIRMS} \text { or ESTBS })_{\mathrm{i}}=\ln \alpha_{0}+\beta \ln \sigma(\pi)_{\mathrm{i}}+\delta \ln \Phi_{\mathrm{i}}+\gamma \ln \mathrm{T}_{\mathrm{i}}+\xi \ln \mathrm{AD}_{\mathrm{i}}+\psi \ln \mathbf{Z}_{\mathrm{i}}+\ln \mathrm{v}_{\mathrm{i}} .
$$

\section{Potential Endogeneity of $\sigma(\pi)$}

The theory indicates that the effects of uncertainty in part may depend on market structure (see discussion at end of section 2.2). Further, market structure itself is likely to be determined by the forces governing entry and exit. While several factors need to fall in place, $\sigma(\pi)$ may be endogenous. Given 
this, we estimate (3) using OLS as well as Instrumental Variables methods and conduct Hausman tests.

For IV estimation, finding industry-specific variable(s) that will be correlated with $\sigma(\pi)_{\mathrm{i}}$ and uncorrelated with the error term $v_{i}$ is a rather difficult proposition. The first instrument we consider is industry-specific energy prices. Industry energy inputs could include coal, electricity, natural gas, petroleum, etc. Arguably, prices of these inputs are being determined in national and global markets. Thus, energy prices can be treated as exogenous to a given SIC 4-digit manufacturing industry. ${ }^{12} \mathrm{We}$ construct a relative energy price variable $e_{i}=\left(\right.$ energy $_{\mathrm{i}} /$ GDP Deflator $)$ and use the standard deviation of $e_{i}$ over our sample period $-\sigma(\mathbf{e})_{i}$ - as an industry-specific instrument for $\sigma(\pi)_{i}$.

We also considered a second instrument related to industry-specific materials prices. For example, for the paper industry, wood-pulp is a critical input along with various chemicals used in production processes. Prices of wood-pulp and chemicals, among others, will comprise the industryspecific materials price for this industry. In some cases these input prices may arguably be determined exogenously to the 4-digit industry under consideration; for example, if steel is a critical input, one could argue that steel prices are typically being determined in broader national and global markets. But in other cases this may not be so; for example, the paper industry is a very large consumer of wood-pulp and if this industry starts growing (contracting) rapidly then it may well influence wood-pulp prices. Thus, materials prices may be exogenous for many industries, but not so in others; a priori this is difficult to resolve. We construct a relative materials price variable $\mathrm{m}_{\mathrm{i}}=($ materials $/ \mathrm{i} / \mathrm{GDP}$ Deflator $)$ and use the standard deviation of $\mathrm{m}_{\mathrm{i}}-\sigma(\mathbf{m})_{\mathrm{i}}$ - as an industry-specific instrument for $\sigma(\pi)_{\mathrm{i}}$.

\section{Data}

Our data are for the U.S. SIC 4-digit manufacturing industries and our full sample includes 266

\footnotetext{
${ }^{12}$ Consider the following about the U.S. manufacturing sector: (1) it accounts for roughly $20 \%$ of GDP and (2) is disaggregated into $450 \mathrm{SIC} 4$-digit industries. Thus a typical 4-digit manufacturing industry is less than $0.05 \%$ of the U.S. economy. Given this, it is difficult to visualize how prices of energy inputs like coal, electricity, gas and petroleum would be endogenous to a given 4-digit industry.
} 
industries. The data appendix provides details about sources, time periods, sample size and measurement of sunk costs and technological change.

\subsection{Industry Structure}

We collected data on the total number of firms in an industry (FIRMS) and the number of establishments (ESTBS). These data are from the 5-yearly Census of Manufactures over 1963-1992 for a total of 7 observations; these data are not available at an annual frequency. To gauge the correspondence between FIRMS and ESTBS, we examined the cross-industry distribution of the ratio [ESTBS/FIRMS]. The $50^{\text {th }}$ percentile value is 1.1 and this rises to 1.6 at the $90^{\text {th }}$ percentile level, indicating a rough correspondence between the number of firms and establishments in an industry. ${ }^{13}$

Our objective is to first compute the standard deviation of FIRMS and ESTBS for each industry; this gives us an industry-specific measure of the intertemporal volatility. Given our sample size, we obtain 266 observations. Then we use equation (3) to examine the determinants of these standard deviations across industries. Our examination of the data on FIRMS and ESTBS revealed that many industries have a distinct trend in these variables over our sample period. These trends could be generated by myriad forces including, for example, changing nature of import-competition and exportorientation, changes in the regulatory environment, among others. It is not the objective of this paper to study these secular long-run trends. Keeping this in mind we detrended the data on FIRMS and ESTBS. For each industry using data for the seven Census years (1963-1992), we estimated the regression

$$
\text { FIRMS }(\text { or ESTBS })_{i}=a+b \text { Trend }_{i}+e_{i}
$$

${ }^{13}$ That is, for each industry we computed the [ESTBS/FIRMS] ratio and then examined the cross-industry distribution of this ratio. The rough correspondence of course conceals the fact that larger firms typically tend to be multi-product and multi-establishment. Since the Census dataset does not contain information on firm size and does not allow us to match establishments to firms, we cannot explore this issue in detail. 
and labeled the detrended data as dFIRMS and dESTBS. Then for each industry we computed the standard deviation of these detrended data, $\sigma(\mathrm{dFIRMS})$ and $\sigma(\mathrm{dESTBS})$. These were used in our estimated regression (3). We also present results with non-detrended data; the standard deviations of which are labeled $\sigma($ FIRMS $)$ and $\sigma($ ESTBS $)$. As we show later, our broad conclusions are not dependent on the specific variable we use, $\sigma(\mathrm{dFIRMS})$ or $\sigma(\mathrm{FIRMS})$. In Table 1 (rows 1 and 2) we present the cross-industry summary statistics on $\sigma(\mathrm{dFIRMS})$ and $\sigma(\mathrm{dESTBS})$, which reveal substantial differences across industries in the volatility of the number of firms and establishments.

\subsection{Sunk Costs}

In section 2 we noted that, abstracting from depreciation considerations, sunk costs corresponded to the non-recoverable component of entry capital investment $\Phi=(\mathrm{r}-\phi) \mathrm{K}$, where $\mathrm{K}$ is the entry capital requirement, $r$ the unit price of new capital and $\phi$ the resale price (or scrap value) of this capital. Unfortunately, obtaining data on $\phi$ is extremely difficult implying that we can't measure $\Phi$ directly for our 266 industries. Instead, we pursue an alternate approach.

The theoretical models (section 2) treat sunk costs as proportional to entry capital requirements. We adopt the methodology outlined in Kessides (1990) and Sutton (1991) to obtain proxies for sunk costs. The extent of sunk capital outlays incurred by a potential entrant will be determined by the durability, specificity and mobility of capital. While these characteristics are unobservable, one can construct proxies. Following Kessides, let RENT denote the fraction of total capital that a firm (entrant) can rent: RENT=(rental payments on plant and equipment/capital stock). Let USED denote the fraction of total capital expenditures that were on used capital goods: USED $=($ expenditures on used plant and equipment/total expenditures on new and used plant and equipment). Finally, let DEPR denote the share of depreciation payments: $\mathrm{DEPR}=($ depreciation payments/capital stock $)$. These proxies are useful because if a potential entrant can buy used capital, or can lease capital, then sunk costs are correspondingly lower. Similarly, depreciation makes capital less sunk; in the limiting scenario if capital 
lives only for one period, then sunk costs, which arise from the non-depreciated component of capital, are negligible. We create the following three measures: $\Phi(\mathbf{R E})=(1 / \mathrm{RENT}) ; \Phi(\mathbf{U S})=(1 / \mathrm{USED})$; and $\Phi(\mathrm{DE})=(1 / \mathrm{DEPR})$. High $\Phi(\mathrm{RE})$ indicates low-intensity rental market, implying higher sunk costs. High $\Phi(\mathrm{US})$ signals low-intensity used capital market, implying higher sunk costs. High $\Phi(\mathrm{DE})$ indicates that capital decays slowly, implying higher sunk costs which arise from the undepreciated portion of capital. The final measure $\Phi(\mathbf{E K})$ is from Sutton (1991); details are provided in the data appendix. This is a measure of median entry capital requirement based on the observed distribution of plant sizes. As in Sutton and the models noted in sections 2.1 and 2.2, sunk costs are assumed to be proportional to $\Phi(E K)$. We collected data to construct $\Phi(\mathrm{RE}), \Phi(\mathrm{US}), \Phi(\mathrm{DE})$ and $\Phi(\mathrm{EK})$ for the Census years 1972, 1982 and $1992 . .^{14}$

In our estimation, we report results with these measures used separately. However, in our baseline specification, we use a "weighted" index of sunk costs capturing elements of all the attributes described above: $\Phi(\mathrm{W})=\left[\phi_{1} \Phi(\mathrm{RE})+\phi_{2} \Phi(\mathrm{US})+\phi_{3} \Phi(\mathrm{DE})+\phi_{4} \Phi(\mathrm{EK})\right]$, where $\phi_{\mathrm{i}}$ 's are the weights. Due to lack of information which can be used to assign optimal weights $\phi$, we assume that $\phi_{\mathrm{i}}=0.25 \forall \mathrm{i}$. For each variable, we use the mean value (computed over 1972,1982 and 1992) in our estimated equation (3). Table 1 presents summary statistics for $\Phi(\mathrm{RE}), \Phi(\mathrm{US}), \Phi(\mathrm{DE}), \Phi(\mathrm{EK})$ and $\Phi(\mathrm{W})$ and Table 2 presents the cross-industry correlations between $\sigma($ FIRMS) and $\sigma($ ESTBS $)$ and the various sunk costs measures. The correlations reveal that industries with higher sunk costs have lower endemic volatility of firms and establishments.

\subsection{Uncertainty}

For the real options models, uncertainty is a key variable. It is also a rather difficult to construct empirically. While theory suggests several state variables that can be used to measure uncertainty, we

\footnotetext{
${ }^{14}$ Collecting these for some of the additional (particularly, earlier) years presented problems due to changing industry definitions and many missing data points. Our data revealed fairly high correlation (between 0.6-0.9) for the sunk cost proxies across the different years, indicating a fair degree of stability in these measures.
} 
use a bottom-line measure - profitability - which is a key concern for firms making entry and exit decisions. Firms are assumed to use a forecasting equation to predict future profits. This filters out the systematic components and the standard deviation of the residuals - the unsystematic component measures profit uncertainty. ${ }^{15}$ We measure industry profitability per unit of sales, assuming that intermediate materials, energy and labor comprise the total variable costs. Our main measure of profitability is given by $\pi$ (measure M1 in table below). ${ }^{16}$

Profitability Measures; Forecasting Specifications; Measures of Uncertainty.

\section{A. Profitability Measures.}

(M1) $\pi=($ Sales Revenue-Variable Costs)/(Sales Revenue)

(M2) $\pi($ depr $)=($ Sales Revenue-Variable Costs-Depreciation Expenditures $) /($ Sales Revenue $)$

\section{B. Forecasting Specifications.}

(S1) $\pi_{\mathrm{i}, \mathrm{t}}=\alpha+\lambda_{\mathrm{j}} \sum_{\mathrm{j}} \pi_{\mathrm{i}, \mathrm{t}-\mathrm{j}}+\xi_{\mathrm{k}} \sum_{\mathrm{k}} \mathrm{SALES}_{\mathrm{i}, \mathrm{t}-\mathrm{k}}+\gamma_{\mathrm{m}} \sum_{\mathrm{m}} \mathrm{UN}_{\mathrm{t}-\mathrm{m}}+\epsilon_{\mathrm{i}, \mathrm{t}}$ Uncertainty measure: $\sigma(\pi: \mathrm{S} 1)$

$(\mathrm{S} 2) \pi_{\mathrm{i}, \mathrm{t}}=\alpha+\lambda_{\mathrm{j}} \sum_{\mathrm{j}} \pi_{\mathrm{i}, \mathrm{t}-\mathrm{j}}+\xi_{\mathrm{k}} \sum_{\mathrm{k}} \mathrm{SALES}_{\mathrm{i}, \mathrm{t}-\mathrm{k}}+\delta_{\mathrm{n}} \sum_{\mathrm{n}} \mathrm{FFR}_{\mathrm{t}-\mathrm{n}}+\tau_{\mathrm{p}} \sum_{\mathrm{p}} \mathrm{ENER}_{\mathrm{t}-\mathrm{p}}+\mathrm{v}_{\mathrm{i}, \mathrm{t}}$ Uncertainty measure: $\sigma(\pi: \mathrm{S} 2)$

(S3) $\pi_{\mathrm{i}, \mathrm{t}}=\alpha+\lambda_{\mathrm{j}} \sum_{\mathrm{j}} \pi_{\mathrm{i}, \mathrm{t}-\mathrm{j}}+\omega_{\mathrm{i}, \mathrm{t}}$ Uncertainty measure: $\sigma(\pi: \mathrm{S} 3)$

(S4) $\pi_{\mathrm{i}, \mathrm{t}}=\alpha+$ trend $+\lambda_{\mathrm{j}} \sum_{\mathrm{j}} \pi_{\mathrm{i}, \mathrm{t}-\mathrm{j}}+\xi_{\mathrm{k}} \sum_{\mathrm{k}} \mathrm{SALES}_{\mathrm{i}, \mathrm{-t}}+\gamma_{\mathrm{m}} \sum_{\mathrm{m}} \mathrm{UN}_{\mathrm{t}-\mathrm{m}}+\mathrm{u}_{\mathrm{i}, \mathrm{t}}$ Uncertainty measure: $\sigma(\mathrm{d} \pi: \mathrm{S} 1)$

The benchmark profit forecasting specification S1 includes lagged values of $\pi$ to capture the

${ }^{15}$ Sutton (1997.a, p.52-53) notes the primary importance of the volatility of industry profits in affecting entry and exit decisions. Our construction of the uncertainty measure is consistent with previous work; see, e.g., Aizenman and Marion (1997), Lensink, Bo and Sterken (2002), Ghosal and Loungani (1996, 2000) and Huizinga (1993). In these studies, the standard deviation (or the conditional standard deviation) of some variable of interest measures uncertainty.

${ }^{16}$ This is consistent with theoretical definition of short-run profits (Varian, 1992, Ch.2). Empirically, this is a commonly used measure; see Carlton and Perloff(1994, Ch.9), Domowitz et al. (1986, 1987), Geroski and Mueller (1990), Ghosal (2000) and Machin and Van Reenen (1993). Carlton and Perloff (p.334-343) and Schmalensee (1989) discuss alternate measures and their pitfalls. Our measure $\Pi$ does not control for capital costs, which are more important for measuring the level of long-run profitability. Carlton and Perloff and Schmalensee note that quantifying capital costs is difficult due to problems related to valuing capital and assessing depreciation. 
variable's own dynamics, industry-specific sales growth (SALES) and economy-wide unemployment rate (UN). The justification for such a specification is contained in Domowitz, Hubbard and Petersen (1986) and Machin and VanReenen (1993) which show the sensitivity of profit-margins to industryspecific and aggregate economic conditions. For each industry in our sample, we first estimate specification S1 using annual data over the entire sample period 1958-1994. ${ }^{17}$ The residuals represent the unsystematic components. The standard deviation of residuals, $\sigma(\pi: \mathbf{S 1})_{\mathbf{i}}$, is our primary industryspecific measure of uncertainty. Table 1 presents the summary statistics on $\sigma(\pi: S 1)$ and Table 2 presents the correlation with $\sigma($ FIRMS $) \sigma($ ESTBS $)$. The correlations indicate that industries with greater uncertainty have lower firm and establishment volatility. These correlations are marginally larger than those observed for the sunk cost proxies.

We conducted the following checks for robustness:

(1) Consider the alternate specifications S2, S3 and S4. The motivation for S2 is from the results in Ghosal (2000) where we replace the broad business cycle indicator, unemployment rate, by the federal funds rate (FFR) and energy price growth (ENERGY). Specification S3 is a basic AR(2) model. Specification S4 is motivated by the argument that for some industries the data on $\pi$ may be nonstationary. If so, the measured standard deviation of $\pi$ will be high. However, this may not necessarily reflect greater uncertainty if the trends are predictable. To control for non-stationarity, we estimate the forecasting equation by including a trend and then measuring uncertainty.

(2) Construct an alternate measure (M2) of profitability $\pi($ depr) which accounts for depreciation expenditures. The data on industry-specific depreciation rates were collected for the Census years 1972, 1982 and 1992 (same as those used to create the DEPR sub-samples). We assumed that these data are representative for the entire sample period and constructed $\pi$ (depr). We used $\pi($ depr $)$ in conjunction with

\footnotetext{
${ }^{17}$ We present some summary statistics from the regressions S1 estimated to measure uncertainty. Across the 266 industries, the mean Adjusted- $\mathrm{R}^{2}$ and the standard deviation of adjusted- $\mathrm{R}^{2}$ were 0.61 and 0.24 , respectively. The first-order serial correlation was typically low, with the cross-industry mean (std. dev across industries) being $-0.019(0.067)$. Overall, the fit of the industry regressions was good.
} 
S1 to compute an alternate measure $\sigma[\pi($ depr $)]$.

In Section 5 we report results for these additional checks; our broad inferences are not affected.

\subsection{Other Control Variables}

As noted in section 2.3, we control for additional factors related to advertising-intensity, industry growth and technology. The data on advertising-intensity (ADVT) are from the detailed FTC line-ofbusiness data (see data appendix). While the data are high quality, they are only available for a limited number of years. In our estimation we assume that the data on ADVT are representative for the full sample period. ${ }^{18}$ Industry growth (GRS) is the mean industry-specific rate of growth of real sales over the sample period. Table 1 presents the summary statistics on ADVT and GRS which reveal large crossindustry differences.

We use two measures of technological progress. The first measure is industry $\mathbf{R} \& \mathbf{D}$ intensity. The basic assumption being that industries with higher R\&D will show greater technological progress and cost-efficiency gains. As noted in the appendix, the R\&D data are from the FTC line-of-business files and are available only for a limited number of years. In our estimation we assume that these data on $R \& D$ are representative for the full sample period. Audretsch (1995, p.27-29) and Cohen and Levin (1989), for example, highlight limitations linking R\&D expenditures to technological change and market opportunities. Given some of the criticisms, we construct a second measure: total factor productivity growth, TFP. For a four-factor (capital stock, K; labor hours H; materials, M; and energy, E) production function, the basic Solow residual is: $\operatorname{TFP}(\mathbf{0})_{t}=\left[\Delta \mathrm{q}_{\mathrm{t}}-\left(\gamma_{\mathrm{k}_{\mathrm{t}}} \Delta \mathrm{k}_{\mathrm{t}}+\gamma_{\mathrm{ht}_{\mathrm{t}}} \Delta \mathrm{h}_{\mathrm{t}}+\gamma_{\mathrm{mt}} \Delta \mathrm{m}_{\mathrm{t}}+\gamma_{\mathrm{et}} \Delta \mathrm{e}_{\mathrm{t}}\right)\right]$, where $\mathrm{q}, \mathrm{k}, \mathrm{h}, \mathrm{m}$ and e are logarithms of output and the four inputs, and $\gamma$. the input share. The literature has shown that there can be significant deviation between true technological change and TFP(0). Inputs like capital have variable "utilization" over the business cycle, imparting a strong procyclical bias to $\operatorname{TFP}(0)$; see Burnside

\footnotetext{
${ }^{18}$ Domowitz, et al. (1986), for example, note that most SIC 4-digit manufacturing industries had reached steadystate values of advertising-intensity by early 1960 's. So considering advertising-intensity data from the mid-point of our sample appears reasonable.
} 
et al. (1995), Burnside (1996) and Basu (1996). Burnside et al. (1995) use electricity consumption to proxy utilization of capital and obtain a corrected Solow residual; other proxies have included total energy consumption and materials inputs. ${ }^{19}$ Following this literature, we construct a factor-utilizationadjusted technology residual $\mathbf{T F P}(\mathbf{m})$ (see data appendix for details). In our estimated regression (3), we use the industry-specific mean value of $\operatorname{TFP}(\mathrm{m})$ computed over the full sample period. Table 1 presents the summary statics on $\mathrm{R} \& \mathrm{D}$ and $\mathrm{TFP}(\mathrm{m})$ and Table 2 presents the cross-industry sample correlations, which show a negative relationship between the measures of innovation and $\sigma($ FIRMS) and $\sigma(\mathrm{ESTBS})$. The relationship is a stronger negative for R\&D as compared to TFP $(\mathrm{m})$.

\section{Estimation Results}

\section{Baseline Results}

These results are reported in Table 3. Columns 1-6 present the results for $\sigma(\mathrm{dFIRMS})$ and $\sigma(\mathrm{dESTBS})$ using OLS and IV methods. As noted in section 3, the standard deviation of industryspecific energy and materials prices, $\sigma(\mathrm{e})_{\mathrm{i}}$ and $\sigma(\mathrm{m})_{\mathrm{i}}$, are used as instruments for the potentially endogenous variable $\sigma(\pi)_{i}$. The raw correlations between $\sigma(\pi)_{i}$ and $\sigma(\mathrm{e})_{\mathrm{i}}$ and $\sigma(\mathrm{m})_{\mathrm{i}}$ are 0.29 and 0.12 , respectively. Given that energy prices are arguably exogenous to a given SIC 4-digit industry, $\sigma(e)_{i}$ is a better instrument. In addition it is more highly correlated with the included potentially endogenous variable $\sigma(\pi)_{\mathrm{i}}$. The Hausman tests cannot reject the null that $\sigma(\pi)_{\mathrm{i}}$ and the error term are uncorrelated. These inferences are the same for the $\sigma(\mathrm{dFIRMS})$ and $\sigma(\mathrm{dESTBS})$ regressions. Finally, while the estimated $\sigma(\pi)_{\mathrm{i}}$ coefficients are larger for the IV estimator, the broad qualitative inferences are similar for the OLS an IV estimates. Given our results, we treat $\sigma(\pi)_{i}$ as exogenous and use the OLS estimates to describe our results.

From Table 3, the $\sigma(\pi)_{\mathrm{i}}$ estimates are negative and highly significant for both $\sigma(\mathrm{dFIRMS})$ and

\footnotetext{
${ }^{19}$ The basic intuition is that these inputs (materials and energy) do not have a cyclical utilization (or "hoarding") component like capital and, therefore, are good proxies for the utilization of capital; e.g., assuming capital stock is constant, if the utilization of capital increases, then materials and energy usage will typically increase.
} 
$\sigma(\mathrm{dESTBS})$. Given the standard errors, the point estimate of $\sigma(\pi)$ is roughly similar for the $\sigma(\mathrm{dFIRMS})$ and $\sigma(\mathrm{dESTBS})$ regressions. The results for the sunk cost measure $\Phi(\mathrm{W})$ indicate the same pattern. Given the standard errors, the $\Phi(\mathrm{W})$ effect is somewhat smaller than the $\sigma(\pi)$ effect. The R\&D coefficient is also negative, but quantitatively much smaller and of lower statistical significance than the uncertainty and sunk cost estimates. The advertising-intensity estimate is also negative but not significant at conventional levels.

Next we focus more closely on uncertainty and sunk costs. Using the estimates from Table 1 (col.1), equation (1) becomes:

$$
\sigma(\mathrm{dFIRMS})_{\mathrm{i}}=13.46 \sigma(\pi: \mathrm{S} 1)_{\mathrm{i}}^{-0.962} \Phi(\mathrm{W})_{\mathrm{i}}^{-0.886} \mathrm{R} \& \mathrm{D}_{\mathrm{i}}^{-0.087} \mathrm{ADVT}_{\mathrm{i}}^{-0.060}
$$

Figures 1-2 provide a graphical look at the estimated relationships. Using (4) above, Figure 1 plots the relationship between $\sigma(\mathrm{dFIRMS})$ and $\sigma(\pi: \mathrm{S} 1)$ assuming all other variables are held at their crossindustry sample mean values. The theory indicates that the negative effect should be greater for initial small values of $\sigma(\pi: \mathrm{S} 1)$ and the incremental effect diminishes as $\sigma(\pi: \mathrm{S} 1)$ gets larger; Figure 1 lends support for this prediction. Similarly, Figure 2 plots the estimated relationship between $\Phi(\mathrm{W})$ and $\sigma(\mathrm{dFIRMS})$. As in the case of $\sigma(\pi: \mathrm{S} 1)$, the relationship displays the pattern predicted by theory. The only difference worth noting is that the graph for $\Phi(\mathrm{W})$ shows greater curvature than $\sigma(\pi: \mathrm{S} 1)$. We don't plot the relationships for $\sigma(\mathrm{dESTBS})$, but they are roughly similar to those for $\sigma(\mathrm{dFIRMS})$.

Regarding the quantitative effects, a natural way of evaluating them is to consider a onestandard-deviation (one-s.d.) change in $\sigma(\pi: \mathrm{S} 1)$ and/or $\Phi(\mathrm{W})$. From Table 1 , the cross-industry standard deviation of $\sigma(\pi: \mathrm{S} 1)$ is 0.011 and $\Phi(\mathrm{W})$ is 29.6 . Using equation (4) and starting from the cross-industry mean values of all variables, if $\sigma(\pi: \mathrm{S} 1)$ increases by one-s.d. from 0.027 to 0.038 , then $\sigma(\mathrm{dFIRMS})$ decreases from 37.72 to 23.24 . Similarly, starting from the mean values of all variables, if $\Phi(\mathrm{W})$ increases by one-s.d. from 32.5 to 62.1 , then $\sigma(\mathrm{dFIRMS})$ decreases from 37.78 to 21.28. Regarding the 
cross-dependence of the $\sigma(\pi: \mathrm{S} 1)$ effect on $\Phi(\mathrm{W})$, consider the following. First, consider $\sigma(\pi: \mathrm{S} 1)$ increasing by one-s.d. from 0.027 to 0.038 which results in $\sigma$ (dFIRMS) decreasing from 37.72 to 23.24 . Second, now let $\Phi(\mathrm{W})$ also increase by one-s.d. This results in $\sigma(\mathrm{dFIRMS})$ decreasing from 23.24 to 14.85. So the combined effects of uncertainty and sunk costs impart a large downward effect on an industry's intertemporal volatility of the number of firms. Overall, the quantitative effects are large and economically meaningful.

We summarize our basic findings as follows:

(1) Higher profit uncertainty and sunk costs are associated with significantly lower volatility of the number of firms and establishments. The relationship is best characterized as non-linear in the manner predicted by the theories discussed in section 2 . The quantitative effects are economically meaningful. (2) The technology effect as captured by $R \& D$ intensity is weakly significant (statistically) for $\sigma(\mathrm{dFIRMS})$; the significance level is higher for $\sigma(\mathrm{dFIRMS})$. Starting from the mean values of all variables, a one-s.d. increase in R\&D intensity lowers $\sigma$ (dFIRMS) from 37.72 to 35.36 . For both $\sigma(\mathrm{dFIRMS})$ and $\sigma(\mathrm{dESTBS})$, the quantitative effect of R\&D is small.

(3) The sign of the advertizing intensity coefficient is negative, but not significant at conventional levels.

\section{Additional Results}

In Tables 4-6 we report some additional results to check the robustness of our baseline findings.

(1) In Table 4 we present some extended results by augmenting our basic equation with the total factor productivity and industry growth variables, TFP(m) and GRS. Neither of these variables appear important in explaining $\sigma(\mathrm{dFIRMS})$ and $\sigma(\mathrm{dESTBS})$. As for Table 3, the Hausman tests cannot reject the null that $\sigma(\pi: \mathrm{S} 1)$ is uncorrelated with the error term. The OLS estimates from Table 4 closely mirror those of Table 3 and our qualitative and quantitative inferences are not affected.

(2) In Table 5 we reproduce the results from Table 3 after dropping the weighted sunk cost measure $\Phi(\mathrm{W})$ and using the individual sunk cost proxies instead. The $\sigma(\pi: \mathrm{S} 1)$ effects are quite similar across 
the four columns. For the sunk cost proxies, the qualitative inferences are similar, but the quantitative effects vary somewhat. The R\&D effects vary in both statistical significance and quantitative effect across the columns. The advertising effect is almost non-existent.

(3) In Table 6 we present additional checks for robustness. For comparison, column A reproduces the results from the first column of Table 3 . The remaining columns are as follows:

(a) In section 4.3 we noted alternate forecasting equations to measure uncertainty: $\sigma(\pi: \mathrm{S} 2), \sigma(\pi: \mathrm{S} 3)$ and $\sigma(\pi: \mathrm{S} 4)$. These results are reported in columns B, C and D;

(b) We considered an alternate measure of profitability $\sigma[\pi(d)]$ which accounts for depreciation expenditures and measuring uncertainty using this. These results are reported in column E;

(c) Our estimation so far used detrended data on FIRMS and ESTBS (equation (4)) to construct the volatility measure. The last column F presents results where the data on FIRMS were not detrended. As is evident from Table 6, these additional checks do not alter our broad conclusions regarding the role played by profit uncertainty and sunk costs in explaining the cross-industry variation in the volatility of the number of firms and establishments. Our baseline results and inferences from Table 3 remain intact.

\section{Discussion}

Our study reveals interesting and economically meaningful effects of sunk capital costs and uncertainty about profits on the volatility of the number of firms and establishments. Figures 1 and 2 display our key findings. Industries with greater sunk capital costs and profit uncertainty show lower intertemporal volatility of firms and establishments. These relationships are non-linear in the sense that initial small increases in sunk costs or profit uncertainty appear to have a relatively larger impact than subsequent increases. To put it differently, small amounts of sunk costs and uncertainty appear sufficient to generate noticeable hysteresis in entry/exit, reducing the volatility of firms and establishments within an industry. This is consistent with the theoretical insights obtained from the real options literature (Dixit, 1989; and Dixit and Pindyck, 1994). The results on technological change are mixed. Using R\&D intensity to proxy 
technical change, we find that greater R\&D lowers firm and establishment volatility. But total factor productivity growth does not explain much of the cross-industry variation in volatility. Advertising intensity appears to have a minimal impact.

Apart from the real options effects described in sections 2.1 and 2.2, there may be additional reasons why $\Phi$ and $\sigma(\pi)$ could influence $\sigma($ FIRMS). For example, firms often rely on external credit for their entry/investment decisions. An important literature has highlighted the role played by profit uncertainty and sunk costs on firms' access to external credit. For conciseness, we only reference the papers directly relevant for our analysis. First, consider profit uncertainty $\sigma(\pi)$. Greenwald and Stiglitz (1990) consider a firm where decision makers maximize expected end-of-period equity minus an expected cost of bankruptcy; the latter plays a key role in decision making. The key results relevant for our analysis are that greater $\sigma(\pi)$ : (1) increases the absolute and incremental risk of bankruptcy at any level of investment since they cannot absorb the increased risk by issuing more equity, and (2) exacerbates borrowing constraints. Thus obtaining capital for entry/investment projects will be more difficult when $\sigma(\pi)$ is greater. ${ }^{20}$ Second, consider sunk costs $\Phi$. The basic result is that lenders will be more reluctant to provide financing if capital embeds large sunk costs (Williamson, 1988; Shleifer and Vishny, 1992) because when asset specificity is high, capital is likely to have low resale value. ${ }^{21}$ Since collateral will have less value, lenders will find it more difficult to recover the loaned capital. Thus, greater $\Phi$ is likely to tighten borrowing constraints, making it more difficult to obtain capital for entry/investment projects. In summary, the access to external credit is likely to be more difficult in industries characterized by high $\sigma(\pi)$ and $\Phi$ as these exacerbate informational asymmetries and tighten

\footnotetext{
${ }^{20}$ Also see Cabral and Mata (2003) on the link between financial market frictions and entry/exit.

${ }^{21}$ Williamson (1988, p.571) writes: "Of the several dimensions with respect to which transactions differ, the most important is the condition of asset specificity. This has a relation to the notion of sunk cost...” (p.580) "In the event of default, the debt-holders will exercise pre-emptive claims against the assets in question....The various debt holders will then realize differential recovery in the degree to which the assets in question are redeployable...the value of a pre-emptive claim declines as the degree of asset specificity deepens...". In Shleifer and Vishny (1992), asset specificity is a determinant of leverage and explains cross-industry and intertemporal patterns of financing; e.g., the ease of debt financing is inversely related to the degree of asset specificity.
} 
borrowing constraints. This will likely lead to lower entry and, consequently, exits. Thus, via the credit market effects, $\sigma($ FIRMS) may be lower. However, to carefully sort out the differential effects of the real options channel versus the credit markets channel, one will need to have detailed data on firm size, financial variables and other firm-specific data. We are pursuing this in our ongoing research.

\section{Implications}

We focus on the potential implications of our findings for competition policy analysis, and understanding labor market dynamics. First, we focus on antitrust/competition policy analysis, and horizontal mergers in particular. The analysis here was conducted using data for SIC 4-digit industries and we cannot make direct linkages to markets as defined in antitrust analysis which tend to be much more disaggregated and detailed. A similar analysis carried out using more disaggregated data may reveal additional insights. Here we draw some broad implications. The U.S. Department of Justice and Federal Trade Commission Horizontal Merger Guidelines (1997) - henceforth, "Guidelines" - notes that the ultimate objective of horizontal merger analysis is to determine (Guidelines, p.3) “...whether the merger is likely to create or enhance market power or to facilitate its exercise. " In evaluating this, the Guidelines contain a detailed analysis of entry. "Uncommitted entrants" are defined as those who are likely to (p.11) “...enter within one year and without the expenditure of significant sunk costs of entry and exit," where sunk costs are defined to include (p.12) “...investments in production facilities, technologies, marketing, $R \& D$, regulatory approvals and testing." In contrast, (p.26) “committed entry” is defined as “...new competition that requires expenditure of significant sunk costs of entry and exit," and the Guidelines (p.25-30) lay out a three-step methodology to assess whether committed entry would counteract a competitive effect of concern. The broad picture that emerges is a clear recognition of the role played by sunk costs in determining entry and the consequent evaluation of competitive effects. Our findings related to sunk costs can be interpreted at two levels. First, our estimates imply that sunk costs are likely to induce entry/exit hysteresis, validating the concerns laid out in the Guidelines. Second, and perhaps 
more importantly, the results appear to indicate that the presence of even small amounts of sunk costs seem sufficient to induce considerable hysteresis. This quantitative result further highlights the need to evaluate sunk costs carefully - even when they are small in magnitude.

Our findings related to uncertainty about profits take on a somewhat newer dimension. Uncertainty is not explicitly mentioned as a factor that may have adverse effects on entry. The received theory (Dixit, 1989; Dixit and Pindyck, 1994) clearly recognizes uncertainty as a key determinant of entry and exit. Our empirical results emphasize the significance of this effect. In addition, we find that the quantitative effect of profit uncertainty is larger than those of sunk capital costs. At a broad brush, this calls for emphasis on uncertainty when evaluating entry and exit and competitive effects in antitrust analysis.

Second, examining the determinants of the volatility of firms and establishments is also important from a wider perspective. For example, what if the number of firms fluctuates due to reallocation of resources with little implication for other variables like employment? So, does the fluctuation of firms correlate with important variables like employment? Our data shows that the crossindustry correlation between the standard deviation of the number of firms and production workers, nonproduction workers and total employment are $0.25,0.42$ and 0.32 , respectively. They are statistically significant and economically meaningful. We conducted a few simple experiments. First, just like for the dependent variable in Eq.(3), we obtained the detrended standard deviation of employment, production workers and non-production workers. Second, we estimated two sets of regressions: (a) regress these employment standard deviations on the standard deviation of the detrended number of firms; and (b) regress the employment standard deviations on the same set of explanatory variables as in Eq.(3). ${ }^{22}$ For (a), about $22 \%-30 \%$ of the volatility in (relevant) industry worker category could be

\footnotetext{
${ }^{22}$ The regressions being: (a) $\ln \sigma(\mathrm{dEMP} \text { or } \mathrm{dPW} \text { or dNPW })_{\mathrm{i}}=\ln \alpha_{0}+\beta \ln \sigma(\mathrm{dFIRMS})_{\mathrm{i}}+\ln \mathrm{e}_{\mathrm{i}}$; and (b) $\ln \sigma(\mathrm{dEMP} \text { or } \mathrm{dPW} \text { or dNPW })_{\mathrm{i}}=\ln \alpha_{0}+\beta \ln \sigma(\pi)_{\mathrm{i}}+\delta \ln \Phi_{\mathrm{i}}+\gamma \ln \mathrm{T}_{\mathrm{i}}+\xi \ln \mathrm{AD}_{\mathrm{i}}+\psi \ln \mathbf{Z}_{\mathrm{i}}+\ln \mathrm{v}_{\mathrm{i}}$, where the dependent variables are the detrended standard deviations of employment, production workers and nonproduction workers.
} 
explained by the volatility of the number of firms alone. For (b), industries with greater profit uncertainty have significantly lower volatility of the employment variables; the sunk cost results are somewhat mixed; and higher R\&D intensity also lowers employment volatility. While a detailed examination of this issue is beyond the scope of this paper, it is clear that examining the forces that govern entry and exit, and influence firm volatility, can shed useful light into labor market dynamics with implications for search models, job creation and entrepreneurship (Fonseca, Lopez-Garcia and Pissarides, 2001; Mortensen and Pissarides, 1998). 


\section{References}

Appelbaum, Elie, and Chin Lim. "Contestable Markets under Uncertainty," RAND Journal of Economics $16,1985,28-40$.

Audretsch, David. Innovation and Industry Evolution. Cambridge: MIT Press, 1995.

Basu, Susanto. "Procyclical Productivity: Increasing Returns or Cyclical Utilization?" Quarterly Journal of Economics 111, 1996, 719-751.

Baumol, William, John Panzar, and Robert Willig. Contestable Markets and the Theory of Industry Structure. San Diego: Harcourt Brace Jovanovich, 1982.

Burnside, Craig. "Production Function Regressions, Returns to Scale, and Externalities," Journal of Monetary Economics 37, 1996, 177-201.

Burnside, Craig, Martin Eichenbaum and Sergio Rebelo. "Capital Utilization and Returns to Scale," National Bureau of Economic Research Macroeconomics Annual, 1995, 67-119.

Caves, Richard, and Michael Porter. "From Entry Barriers to Mobility barriers," Quarterly Journal of Economics 9, 241-267.

Cohen, Wesley and Richard Levin. "Empirical Studies of Innovation and Market Structure" in Schmalensee, Richard and Robert Willig, ed., Handbook of Industrial Organization, Amsterdam: North Holland, (1989).

Cooley, Thomas and Vincenzo Quadrini. "Financial Markets and Firm Dynamics," American Economic Review, 2001, 1286-1310.

Cabral, Luis, and José Mata. "On the Evolution of the Firm Size Distribution: Facts and Theory," American Economic Review, 2003, forthcoming.

Davis, Steven, John Haltiwanger and Scott Schuh. Job Creation and Destruction. MIT Press, 1996.

Dixit, Avinash. "Role of Investment in Entry Deterrence," Economic Journal 90, 95-106.

Dixit, Avinash. "Entry and Exit Decisions under Uncertainty," Journal of Political Economy 97, 1989, 620-638.

Dixit, Avinash, and Robert Pindyck. Investment under Uncertainty. Princeton: Princeton University Press, 1996.

Domowitz, Ian, Glenn Hubbard and Bruce Petersen. "Business Cycles and the Relationship Between Concentration and Price-Cost Margins," RAND Journal of Economics 17, 1986, 1-17. 
Driver, Ciaran and Brendan Whelan. "The Effect of Business Risk on Manufacturing Investment," Journal of Economic Behavior and Organization 44, 2001, 403-412.

Driver, Ciaran, Katsushi Imai, Paul Temple and Giovanni Urga. "Explaining the Diversity of Industry Responses to Uncertainty Using Long-Run Panel Survey Data," Imperial College (University of London), U.K., 2002.

Dunne, Timothy, Mark Roberts, and Larry Samuelson. "Patterns of entry and exit in U.S. manufacturing industries," RAND Journal of Economics 19, 1988, 495-515.

Fazzari, Steven, Glenn Hubbard and Bruce Petersen, "Financing Constraints and Corporate Investment." Brookings Papers on Economic Activity 1 (1988), 141-195.

Fonseca, Raquel, Paloma Lopez-Garcia, and Christopher Pissarides. "Entrepreneurship, Startup Costs and Employment," European Economic Review 45, 2001, 692-705.

Geroski, Paul, and Dennis Mueller. "The Persistence of Profits in Perspective," in Dennis Mueller (ed.), The Dynamics of Company Profits. Cambridge: Cambridge University Press, 1990.

Geroski, Paul, and Joachim Schwalbach. Entry and Market Contestability. Oxford: Blackwell, 1991.

Ghosal, Vivek. "The Impact of Uncertainty and Sunk Costs on Firm Survival and Industry Dynamics," Georgia Institute of Technology, 2002.

Ghosal, Vivek. "Product Market Competition and Industry Price-Cost Margin Fluctuations: Role of Energy Price and Monetary Changes," International Journal of Industrial Organization 18, 2000, 415444.

Ghosal, Vivek and Prakash Loungani. "The Differential Impact of Uncertainty on Investment in Small and Large Businesses," The Review of Economics and Statistics 82, 2000, 338-343.

Ghosal, Vivek and Prakash Loungani. "Product Market Competition and the Impact of Price Uncertainty on Investment," Journal of Industrial Economics 44, 1996, 217-228.

Gort, Michael and Steven Klepper. "Time Paths in the Diffusion of Product Innovations," Economic Journal 92, 1982, 630-653.

Greenwald, Bruce and Joseph Stiglitz. "Macroeconomic Models with Equity and Credit Rationing," in Hubbard, R. Glenn. ed., Asymmetric Information, Corporate Finance, and Investment. Chicago: University of Chicago Press, 1990, 15-42.

Huizinga, John, "Inflation Uncertainty, Relative Price Uncertainty and Investment in U.S. Manufacturing industries," Journal of Money, Credit, and Banking 25, 1993, 521-549.

Jovanovic, Boyan. “Selection and Evolution of Industry," Econometrica 50, 1982, 649-670. 
Jovanovic, Boyan and Glenn MacDonald. "The Life Cycle of a Competitive Industry," Journal of Political Economy 102, 1994, 322-347.

Kessides, Ioannis. "Market Concentration, Contestability and Sunk Costs," Review of Economics and Statistics 72, 1990, 614-622.

Kessides, Ioannis. "Advertising, Sunk Costs and Barriers to Entry," Review of Economics and Statistics $68,1986,84-95$.

Lensink, Robert, Hong Bo, and Elmer Sterken. Investment, Capital Market Imperfections, and Uncertainty. Edward Elgar. 2001.

Mortensen, Dale, and Christopher Pissarides. "Technological Progress, Job Creation and Job Destruction," Review of Economic Dynamics 1, 1998, 733-753.

Pakes, Ariel, and Richard Ericson. "Empirical Implications of Alternate Models of Firm Dynamics," Journal of Economic Theory 79, 1998, 1-45.

Rosenberg, Mats. "Does Uncertainty Affect Investment and Labor Demand?" Swedish School of Economics and Business Administration, 2002.

Schmalensee, Richard, "Inter-Industry Studies of Structure and Performance," in Schmalensee, Richard and Robert Willig, ed., Handbook of Industrial Organization, Amsterdam: North Holland, (1989).

Shleifer, Andrei, and Robert Vishny. "Liquidation Values and Debt Capacity: A Market Equilibrium Approach,"Journal of Finance 47, 1992, 1343-1366.

Spence, Michael. "Entry, Capacity, Investment and Oligopolistic Pricing," Bell Journal of Investment $8,534-544$.

Spencer, Barbara, and James Brander. "Pre-Commitment and Flexibility: Applications to Oligopoly Theory," European Economic Review 36, 1992, 1601-1626.

Sutton, John. Sunk Costs and Market Structure. Cambridge: MIT Press, 1991.

Sutton, John. “Gibrat's Legacy,” Journal of Economic Literature 35, 1997 (a), 40-59.

Sutton, John. Technology and Market Structure. Cambridge: MIT Press, 1997(b).

U.S. Department of Justice and Federal Trade Commission. Horizontal Merger Guidelines, 1997.

Williamson, Oliver. “Corporate Finance and Corporate Governance," Journal of Finance, 1988, 567-91.

Winter, Sidney. "Schumpeterian Competition in Alternative Technological Regimes," Journal of Economic Behavior and Organization 5, 1984, 287-320. 


\section{Appendix A: Data Sources, Variables and Measurement.}

\section{A. The U.S. SIC 4-Digit Manufacturing Industry Database.}

\begin{tabular}{|l|l|l|}
\hline Variable & Source & Years Available \\
\hline $\begin{array}{l}\text { Industry time-series data: } \\
\text { sales, investment, capital } \\
\text { stock, costs, etc. }\end{array}$ & $\begin{array}{l}\text { Bartlesman and Gray (1998): } \\
\text { Annual Survey and Census of } \\
\text { Manufacturing. }\end{array}$ & $1958-1994$ \\
\hline $\begin{array}{l}\text { Number of firms and } \\
\text { establishments. }\end{array}$ & Census of Manufacturing & $1963,67,72,77,82,87,92$. \\
\hline Used capital expenditures. & Census of Manufacturing & $1972,82,92$. \\
\hline Rental payments. & Census of Manufacturing & $1972,82,92$. \\
\hline Depreciation payments. & Census of Manufacturing & $1972,82,92$. \\
\hline R\&D Intensity. & FTC Line-of-Business Data & $1975-1978$ \\
\hline Advertizing Intensity. & FTC Line-of-Business Data & $1975-1978$ \\
\hline $\begin{array}{l}\text { Aggregate variables: } \\
\text { unemployment rate, federal } \\
\text { funds rate, energy prices. }\end{array}$ & $\begin{array}{l}\text { Economic Report of the } \\
\text { President. }\end{array}$ & $1958-1994$. \\
\hline
\end{tabular}

The following industries were excluded from the sample: (i) "Not elsewhere classified" since they do not correspond to well defined product markets; (ii) Industries that could not be matched properly over time due to SIC definitional changes; there were important definition changes in 1972 and 1987. For these industries, the industry time-series and other structural characteristics data are not comparable over the sample period; and (iii) Industries that had missing data on the industry structure, sunk cost, R\&D or advertising variables. The final sample contains 266 SIC 4-digit manufacturing industries. Given the above exclusions, the final sample contains industries that are mature and well defined over the sample period and have data consistency.

We use the FTC line-of-business data for R\&D and advertizing. The data are high quality and have been used in many studies. Unfortunately they are available only for a few years and were discontinued. In addition, some of the data are at the SIC 3-digit level. Where data were available only at the 3-digit level, all the underlying 4-digit industries were assumed to have the same values. I am not aware of the availability of SIC 4-digit data for R\&D and advertizing for all our industries over the 30 year period.

\section{B. Sunk Entry Capital Requirements.}

The construction here follows Sutton $(1991$, Ch.2). Let $\xi(>0)$ be defined as the setup cost or the minimal level of sunk cost that an entrant must incur, and S denote total industry sales (market size). Thus, in theory, $\xi / \mathrm{S}$ is the sunk cost relative to market size. In quantifying setup/sunk costs (Sutton 1991, Ch.4), 
he proposes a proxy that measures the "relative" level of setup costs across industries. Sunk costs are assumed to be proportional to the cost of constructing a single plant of minimum efficient scale (MES). Let $\Psi$ be a measure of MES, where $\Psi$ is the output of the median plant relative to industry output. Assume that the capital-sales ratio of the median firm is the same as the industry as a whole and denote industry capital-sales ratio by $\mathrm{K} / \mathrm{S}$. Then $(\xi / \mathrm{S})=\Psi(\mathrm{K} / \mathrm{S})$. If we can obtain a proxy for $\Psi$, and have data for industry $\mathrm{K}$ and $\mathrm{S}$, we can approximate $\xi / \mathrm{S}$. $\Psi$ is constructed using the distribution of plants within each SIC 4-digit industry according to employment size. Let ' $\mathrm{m}$ ' be the number of group sizes within the industry, and ' $n_{j}$ ' and ' $S_{j}$ ' denote number of plants and total sales of the $j^{\text {th }}$ size group $(j=1, \ldots, m$. $)$. Let $\mathrm{Ms}_{\mathrm{j}}=\left(\mathrm{S}_{\mathrm{j}} / \mathrm{n}_{\mathrm{j}}\right) ; \mathrm{S}_{\mathrm{e}}=(1 / \mathrm{m}) \Sigma_{\mathrm{j}}\left(\mathrm{Ms}_{\mathrm{j}}\right)$; and $\mathrm{S}_{\mathrm{o}}=\Sigma_{\mathrm{j}} \mathrm{S}_{\mathrm{j}}$. Then $\Psi=\left(\mathrm{S}_{\mathrm{e}} / \mathrm{S}_{\mathrm{o}}\right)$. Using $\Psi$ and industry $\mathrm{K} / \mathrm{S}$, we obtain a proxy for $\xi / \mathrm{S}$. We label the term $\Psi(\mathrm{K} / \mathrm{S})$ as $\Phi(\mathbf{E K})$ (sunk costs - entry capital). As noted by Sutton (p.98), the cross-industry variation in $\Phi(\mathrm{EK})$ provides a rough proxy for the cross-industry variation in sunk costs. ${ }^{23}$ We obtained data to calculate $\Phi(E K)$ for the Census years, 1972, 1982 and 1992 (same time periods as for $\Phi(\mathrm{RE}), \Phi(\mathrm{US})$ and $\Phi(\mathrm{DE}))$.

\section{Factor-Utilization Adjusted Solow Residual.}

Burnside (1996) assumes that gross output $Q$ is a differentiable function of unobserved capital "services" $(S)$, labor hours $(H)$, materials $(M)$ and energy $(E)$ : $Q_{t}=Z_{t} F\left(S_{t}, H_{t}, M_{t}, E_{t}\right)$, where $Z$ represents exogenous technology shock. Assuming that $S$ is proportional to materials usage (Basu, 1996), or energy consumption (Burnside, 1996), and competitive factor markets, the log-linear approximation to the production function gives us the adjusted technology residual TFP(m):

(C.1) $\operatorname{TFP}(\mathrm{m})=\left[\Delta \mathrm{q}_{\mathrm{t}}-\left(\delta_{\mathrm{Kt}} \Delta \mathrm{e}_{\mathrm{t}}+\delta_{\mathrm{Ht}} \Delta \mathrm{h}_{\mathrm{t}}+\delta_{\mathrm{Mt}} \Delta \mathrm{m}_{\mathrm{t}}+\delta_{\mathrm{Et}} \Delta \mathrm{e}_{\mathrm{t}}\right)\right]$,

where lower case letters denote logarithms, $\delta$ is the share of the input in total revenue and $\Delta \mathrm{S}$ is replaced by $\Delta \mathrm{m}$ (Basu), or $\Delta \mathrm{e}$ (Burnside). In our experiments and empirical results, it did not matter whether we replaced $\Delta \mathrm{S}$ by $\Delta \mathrm{m}$ or $\Delta \mathrm{e}$. Given that $\Delta \mathrm{m}$ is a broad based measure of input usage, we report results with $\Delta \mathrm{m}$ as the proxy for $\Delta \mathrm{s}$. We use TFP(m) as our benchmark measure of technological change.

Finally, we note an important issue with these computations; there are observations which generate negative TFP values. This problem cannot be eliminated completely and has been extensively discussed in the literature. Apart from cyclicality adjustments, some of the problems relate to input quality improvements and the treatment of factor-share coefficients. Regarding the latter, in our construction we have assumed that the shares of labor, materials, capital, etc, are constant throughout the sample period. But if there is labor-saving innovation or innovation that increases materials intensity over the sample period, then the constructed TFP measures will be biased.

\footnotetext{
${ }^{23}$ Sutton notes limitations of this proxy. For example, (i) he assumes that the capital-output ratio of the median plant is representative of the entire industry, and this is unlikely to be the case; (ii) the book value of capital assets is used to compute the capital-sales ratio, but the book value underestimates the current replacement cost; (iii) the computation assumes that the age structure of capital does not vary across industries, and this is unrealistic.
} 


\section{Table 1. Cross-Industry Summary Statistics.}

\begin{tabular}{|c|c|c|c|c|c|}
\hline & & & \multicolumn{3}{|c|}{ Percentile Distribution } \\
\hline & Mean & s.d. & $25^{\text {th }}$ & $50^{\text {th }}$ & $75^{\text {th }}$ \\
\hline$\sigma(\mathrm{dFIRMS})_{\mathrm{i}}$ & 120.8 & 181.2 & 22.1 & 54.1 & 135.2 \\
\hline$\sigma(\mathrm{dESTBS})_{\mathrm{i}}$ & 129.7 & 188.1 & 22.6 & 61.5 & 143.6 \\
\hline$\sigma(\pi: S 1)_{\mathrm{i}}$ & 0.027 & 0.011 & 0.019 & 0.025 & 0.032 \\
\hline$\Phi(\mathrm{W})_{\mathrm{i}}$ & 32.5 & 29.6 & 14.6 & 22.2 & 37.4 \\
\hline$\Phi(\mathrm{RE})_{\mathrm{i}}$ & 90.1 & 94.6 & 28.8 & 55.5 & 107.5 \\
\hline$\Phi(\mathrm{US})_{\mathrm{i}}$ & 21.5 & 37.8 & 8.4 & 12.6 & 18.3 \\
\hline$\Phi(\mathrm{DE})_{\mathrm{i}}$ & 18.5 & 4.9 & 15.2 & 17.9 & 20.9 \\
\hline$\Phi(\mathrm{EK})_{\mathrm{i}}$ & 0.014 & 0.060 & 0.003 & 0.005 & 0.012 \\
\hline$R \& D_{i}$ & 0.010 & 0.011 & 0.004 & 0.006 & 0.015 \\
\hline $\mathrm{ADVT}_{i}$ & 0.018 & 0.024 & 0.004 & 0.009 & 0.023 \\
\hline $\operatorname{TFP}(\mathrm{m})_{\mathrm{i}}$ & 0.008 & 0.009 & 0.000 & 0.005 & 0.012 \\
\hline GRS $_{i}$ & 0.019 & 0.023 & 0.007 & 0.019 & 0.033 \\
\hline
\end{tabular}

There are 266 SIC 4-digit manufacturing industries in the sample. See data appendix for details.

\section{Dependent Variables}

$\sigma(\mathrm{dFIRMS})_{\mathrm{i}}$ : $\quad$ Standard deviation of the (linearly detrended) total number of firms over 1963-92.

$\sigma(\mathrm{dESTBS})_{\mathrm{i}}$ : $\quad$ Standard deviation of the (linearly detrended) total number of establishments over 1963-92.

First, for each industry, we linearly detrended the data on the number of firms. Second, for each industry, we computed the standard deviation of the (detrended) number of firms over the 7 Census years. Thus, for each industry, we get a measure of endemic volatility of the number of firms $\sigma(\mathrm{dFIRMS})_{\mathrm{i}}$; given our sample, we have 266 observations for this variable. The table presents the cross-industry summary statistics of $\sigma(\mathrm{dFIRMS})_{\mathrm{i}}$ 's. For the median industry, $\sigma(\mathrm{dFIRMS})$ was 54 , with the 25 th and 75 th percentile values being 22 and 135 . We repeated this exercise for the total number of establishments to get $\sigma(\mathrm{dESTBS})_{\mathrm{i}}$. Later, we also present results with firm volatility computed from non-detrended data.

\section{Explanatory Variables}

$\sigma(\pi: \mathrm{S} 1)_{\mathrm{i}}$ : $\quad$ Profit uncertainty.

$\Phi(\mathrm{W})_{\mathrm{i}}: \quad$ Sunk costs - weighted average sunk capital cost measure.

$\Phi(\mathrm{RE})_{\mathrm{i}}$ : $\quad$ Sunk costs - rental intensity.

$\Phi(\mathrm{US})_{\mathrm{i}}$ : $\quad$ Sunk costs - used capital intensity.

$\Phi(\mathrm{DE})_{\mathrm{i}}$ : $\quad$ Sunk costs - depreciation.

$\Phi(\mathrm{EK})_{\mathrm{i}}$ : $\quad$ Sunk costs - entry capital.

R\&D : $\quad$ Research and development intensity.

$\mathrm{ADVT}_{\mathrm{i}}$ : $\quad$ Advertising intensity.

TFP $(m)_{i}$ : $\quad$ Industry average total factor productivity growth over the sample period.

GRS : $\quad$ Sales growth. 


\begin{tabular}{|c|c|c|c|c|c|c|c|c|c|c|}
\hline$\sigma(\mathrm{dFIRMS})$ & -0.337 & -0.290 & -0.293 & -0.143 & -0.260 & -0.107 & -0.151 & 0.020 & -0.079 & 0.084 \\
\hline$\sigma(\mathrm{dESTBS})$ & -0.345 & -0.292 & -0.296 & -0.150 & -0.251 & -0.109 & -0.161 & 0.024 & -0.089 & 0.081 \\
\hline
\end{tabular}

See table 1 for variable definitions. 
Table 3. Baseline Results.

\begin{tabular}{|c|c|c|c|c|c|c|}
\hline & \multicolumn{6}{|c|}{ Dependent Variable } \\
\hline & \multicolumn{3}{|c|}{$\sigma(\mathrm{dFIRMS})_{\mathrm{i}}$} & \multicolumn{3}{|c|}{$\sigma(\mathrm{dESTBS})_{\mathrm{i}}$} \\
\hline $\begin{array}{l}\text { Estimation Method } \\
\text { Instrument(s) for } \sigma(\pi)_{i}\end{array}$ & $\begin{array}{r}\text { OLS } \\
-\end{array}$ & $\begin{array}{r}\text { IV } \\
\sigma(e)_{i}\end{array}$ & $\begin{array}{r}\text { IV } \\
\sigma(e)_{i} ; \sigma(m)_{i}\end{array}$ & $\begin{array}{r}\text { OLS } \\
-\end{array}$ & $\begin{array}{r}\text { IV } \\
\sigma(\mathrm{e})_{\mathrm{i}}\end{array}$ & $\begin{array}{r}\text { IV } \\
\sigma(\mathrm{e})_{\mathrm{i}} ; \sigma(\mathrm{m})_{\mathrm{i}}\end{array}$ \\
\hline $\begin{array}{l}\sigma(\pi: \mathrm{S} 1)_{\mathrm{i}} \\
\text { Profit Uncertainty }\end{array}$ & $\begin{array}{l}-0.962 \\
(0.001)\end{array}$ & $\begin{array}{r}-1.847 \\
(0.018)\end{array}$ & $\begin{array}{l}-1.575 \\
(0.029)\end{array}$ & $\begin{array}{l}-1.044 \\
(0.001)\end{array}$ & $\begin{array}{r}-1.531 \\
(0.022)\end{array}$ & $\begin{array}{l}-1.492 \\
(0.020)\end{array}$ \\
\hline $\begin{array}{l}\Phi(\mathrm{W})_{\mathrm{i}} \\
\text { Sunk Cost - } \\
\text { Weighted Index }\end{array}$ & $\begin{array}{r}-0.886 \\
(0.001)\end{array}$ & $\begin{array}{r}-0.771 \\
(0.001)\end{array}$ & $\begin{array}{r}-0.806 \\
(0.001)\end{array}$ & $\begin{array}{r}-0.815 \\
(0.001)\end{array}$ & $\begin{array}{r}-0.752 \\
(0.001)\end{array}$ & $\begin{array}{r}-0.757 \\
(0.001)\end{array}$ \\
\hline $\begin{array}{l}\mathrm{R} \& \mathrm{D}_{\mathrm{i}} \\
R \& D \text { Intensity }\end{array}$ & $\begin{array}{r}-0.087 \\
(0.095)\end{array}$ & $\begin{array}{r}-0.078 \\
(0.119)\end{array}$ & $\begin{array}{r}-0.081 \\
(0.105)\end{array}$ & $\begin{array}{r}-0.122 \\
(0.014)\end{array}$ & $\begin{array}{r}-0.118 \\
(0.016)\end{array}$ & $\begin{array}{r}-0.118 \\
(0.015)\end{array}$ \\
\hline $\begin{array}{l}\mathrm{ADVT}_{\mathrm{i}} \\
\text { Advertising Intensity }\end{array}$ & $\begin{array}{r}-0.060 \\
(0.170)\end{array}$ & $\begin{array}{r}-0.078 \\
(0.114)\end{array}$ & $\begin{array}{r}-0.073 \\
(0.141)\end{array}$ & $\begin{array}{l}-0.058 \\
(0.139)\end{array}$ & $\begin{array}{r}-0.068 \\
(0.119)\end{array}$ & $\begin{array}{r}-0.067 \\
(0.129)\end{array}$ \\
\hline Intercept & $\begin{array}{r}2.572 \\
(0.002)\end{array}$ & $\begin{array}{l}-1.114 \\
(0.736)\end{array}$ & $\begin{array}{r}0.017 \\
(0.995)\end{array}$ & $\begin{array}{r}1.983 \\
(0.013)\end{array}$ & $\begin{array}{r}-0.040 \\
(0.988)\end{array}$ & $\begin{array}{r}0.122 \\
(0.964)\end{array}$ \\
\hline $\begin{array}{l}\overline{\mathbf{R}}^{2} \\
\text { Hausman Test }\end{array}$ & $\begin{array}{r}0.390 \\
-\end{array}$ & $\begin{array}{r}0.327 \\
(0.779)\end{array}$ & $\begin{array}{r}0.360 \\
(0.678)\end{array}$ & $\begin{array}{r}0.405 \\
-\end{array}$ & $\begin{array}{r}0.384 \\
(0.734)\end{array}$ & $\begin{array}{r}0.387 \\
(0.684)\end{array}$ \\
\hline
\end{tabular}

1. All samples contain 266 industries (see data appendix). The $p$-values (two-tailed) from heteroscedasticity-consistent standard errors are in parentheses. For $p$-values $\leq 0.001$, they are indicated as 0.001 . The number for the Hausman test is the $p$-value for the $\chi^{2}$ test.

2. For variable definitions see table 1 . The instrumental variables for IV estimation are:

$\sigma(\mathrm{e}): \quad$ Standard deviation of industry-specific real energy price.

$\sigma(m)$ : Standard deviation of industry-specific real materials price. 


\begin{tabular}{|c|c|c|c|c|c|c|}
\hline & \multicolumn{6}{|c|}{ Dependent Variable } \\
\hline & \multicolumn{3}{|c|}{$\sigma(\mathrm{dFIRMS})_{\mathrm{i}}$} & \multicolumn{3}{|c|}{$\sigma(\mathrm{dESTBS})_{\mathrm{i}}$} \\
\hline $\begin{array}{l}\text { Estimation Method } \\
\text { Instrument }(\mathrm{s}) \text { for } \sigma(\pi)_{\mathrm{i}}\end{array}$ & $\begin{array}{c}\text { OLS } \\
-\end{array}$ & $\begin{array}{r}\text { IV } \\
\sigma(e)_{i} \\
\end{array}$ & $\begin{array}{r}\text { IV } \\
\sigma(\mathrm{e})_{\mathrm{i}} ; \sigma(\mathrm{m})_{\mathrm{i}} \\
\end{array}$ & $\begin{array}{c}\text { OLS } \\
-\end{array}$ & $\begin{array}{r}\text { IV } \\
\sigma(\mathrm{e})_{\mathrm{i}}\end{array}$ & $\begin{array}{r}\text { IV } \\
\sigma(\mathrm{e})_{\mathrm{i}} ; \sigma(\mathrm{m}) \\
\end{array}$ \\
\hline $\begin{array}{l}\sigma(\pi: \mathrm{S} 1)_{\mathrm{i}} \\
\text { Profit Uncertainty }\end{array}$ & $\begin{array}{r}-0.962 \\
(0.001)\end{array}$ & $\begin{array}{r}-1.918 \\
(0.020)\end{array}$ & $\begin{array}{l}-1.709 \\
(0.031)\end{array}$ & $\begin{array}{r}-1.040 \\
(0.001)\end{array}$ & $\begin{array}{l}-1.559 \\
(0.028)\end{array}$ & $\begin{array}{l}-1.545 \\
(0.027)\end{array}$ \\
\hline $\begin{array}{l}\Phi(\mathrm{W})_{\mathrm{i}} \\
\text { Sunk Costs - } \\
\text { Weighted Index }\end{array}$ & $\begin{array}{r}-0.894 \\
(0.001)\end{array}$ & $\begin{array}{r}-0.793 \\
(0.001)\end{array}$ & $\begin{array}{r}-0.815 \\
(0.001)\end{array}$ & $\begin{array}{r}-0.820 \\
(0.001)\end{array}$ & $\begin{array}{r}-0.765 \\
(0.001)\end{array}$ & $\begin{array}{l}-0.767 \\
(0.001)\end{array}$ \\
\hline $\begin{array}{l}\mathrm{R} \& \mathrm{D}_{\mathrm{i}} \\
R \& D \text { Intensity }\end{array}$ & $\begin{array}{r}-0.086 \\
(0.090)\end{array}$ & $\begin{array}{r}-0.057 \\
(0.308)\end{array}$ & $\begin{array}{r}-0.064 \\
(0.241)\end{array}$ & $\begin{array}{r}-0.124 \\
(0.011)\end{array}$ & $\begin{array}{r}-0.108 \\
(0.036)\end{array}$ & $\begin{array}{r}-0.108 \\
(0.031)\end{array}$ \\
\hline $\begin{array}{l}\mathrm{ADVT}_{\mathrm{i}} \\
\text { Advertising Intensity }\end{array}$ & $\begin{array}{r}-0.062 \\
(0.156)\end{array}$ & $\begin{array}{r}-0.080 \\
(0.109)\end{array}$ & $\begin{array}{r}-0.076 \\
(0.127)\end{array}$ & $\begin{array}{r}-0.059 \\
(0.129)\end{array}$ & $\begin{array}{r}-0.069 \\
(0.114)\end{array}$ & $\begin{array}{l}-0.069 \\
(0.121)\end{array}$ \\
\hline $\begin{array}{l}\operatorname{TFP}(\mathrm{m})_{\mathrm{i}} \\
\text { Total Factor Productivity }\end{array}$ & $\begin{array}{r}0.007 \\
(0.681)\end{array}$ & $\begin{array}{r}0.007 \\
(0.702)\end{array}$ & $\begin{array}{r}0.007 \\
(0.696)\end{array}$ & $\begin{array}{r}0.006 \\
(0.728)\end{array}$ & $\begin{array}{r}0.006 \\
(0.735)\end{array}$ & $\begin{array}{r}0.006 \\
(0.734)\end{array}$ \\
\hline $\begin{array}{l}\text { GRS }_{i} \\
\text { Growth of Sales }\end{array}$ & $\begin{array}{r}-0.434 \\
(0.901)\end{array}$ & $\begin{array}{r}-4.105 \\
(0.414) \\
\end{array}$ & $\begin{array}{r}-3.302 \\
(0.502) \\
\end{array}$ & $\begin{array}{r}0.030 \\
(0.993) \\
\end{array}$ & $\begin{array}{r}-2.025 \\
(0.653) \\
\end{array}$ & $\begin{array}{r}-1.971 \\
(0.664) \\
\end{array}$ \\
\hline Intercept & $\begin{array}{r}2.646 \\
(0.002)\end{array}$ & $\begin{array}{r}-1.074 \\
(0.742)\end{array}$ & $\begin{array}{r}-0.261 \\
(0.933)\end{array}$ & $\begin{array}{r}2.040 \\
(0.013)\end{array}$ & $\begin{array}{r}0.108 \\
(0.994)\end{array}$ & $\begin{array}{r}0.073 \\
(0.979)\end{array}$ \\
\hline $\begin{array}{l}\overline{\mathbf{R}}^{2} \\
\text { Hausman Test }\end{array}$ & 0.391 & $\begin{array}{r}0.321 \\
(0.942)\end{array}$ & $\begin{array}{r}0.348 \\
(0.565)\end{array}$ & $\begin{array}{r}0.404 \\
-\end{array}$ & $\begin{array}{r}0.382 \\
(0.948)\end{array}$ & $\begin{array}{r}0.384 \\
(0.866)\end{array}$ \\
\hline
\end{tabular}

See tables 1 and 3 for details. The new explanatory variables included in this table are:

GRS: Industry average rate of growth of real sales over the sample period. (Note that since some industries are declining and have negative average growth over the sample period, we cannot enter this variable in logarithms like the other variables. Thus, the coefficient estimates of GRS are not readily comparable with the others.) 
Table 5. Additional Results.

Use Individual Sunk Cost Measures.

Dependent Variable: $\sigma(d F I R M S)$.

Estimation Method: OLS.

\begin{tabular}{|c|c|c|c|c|}
\hline $\begin{array}{l}\sigma(\pi: \mathrm{S} 1)_{\mathrm{i}} \\
\text { Profit Uncertainty }\end{array}$ & $\begin{array}{r}-1.051 \\
(0.001)\end{array}$ & $\begin{array}{r}-1.173 \\
(0.001)\end{array}$ & $\begin{array}{l}-1.086 \\
(0.001)\end{array}$ & $\begin{array}{r}-1.102 \\
(0.006)\end{array}$ \\
\hline $\begin{array}{l}\Phi(\mathrm{RE})_{\mathrm{i}} \\
\text { Sunk Costs - } \\
\text { Rental Intensity }\end{array}$ & $\begin{array}{r}-0.626 \\
(0.001)\end{array}$ & - & - & - \\
\hline $\begin{array}{l}\Phi(\mathrm{US})_{\mathrm{i}} \\
\text { Sunk Costs - } \\
\text { Used Intensity }\end{array}$ & - & $\begin{array}{r}-0.553 \\
(0.001)\end{array}$ & - & - \\
\hline $\begin{array}{l}\Phi(\mathrm{DE})_{\mathrm{i}} \\
\text { Sunk Costs - } \\
\text { Depreciation }\end{array}$ & - & - & $\begin{array}{r}-1.337 \\
(0.001)\end{array}$ & - \\
\hline $\begin{array}{l}\Phi(\mathrm{EK})_{\mathrm{i}} \\
\text { Sunk Costs - } \\
\text { Entry Capital }\end{array}$ & - & - & - & $\begin{array}{r}-0.769 \\
(0.001)\end{array}$ \\
\hline $\begin{array}{l}\mathrm{R} \& \mathrm{D}_{\mathrm{i}} \\
R \& D \text { Intensity }\end{array}$ & $\begin{array}{r}-0.084 \\
(0.111)\end{array}$ & $\begin{array}{r}-0.136 \\
(0.013)\end{array}$ & $\begin{array}{r}-0.224 \\
(0.001)\end{array}$ & $\begin{array}{r}0.014 \\
(0.781)\end{array}$ \\
\hline $\begin{array}{l}\mathrm{ADVT}_{\mathrm{i}} \\
\text { Advertising Intensity }\end{array}$ & $\begin{array}{r}-0.069 \\
(0.127)\end{array}$ & $\begin{array}{r}0.034 \\
(0.439)\end{array}$ & $\begin{array}{r}0.012 \\
(0.789)\end{array}$ & $\begin{array}{r}0.010 \\
(0.784)\end{array}$ \\
\hline Intercept & $\begin{array}{r}1.916 \\
(0.020)\end{array}$ & $\begin{array}{r}0.616 \\
(0.447)\end{array}$ & $\begin{array}{r}2.778 \\
(0.026)\end{array}$ & $\begin{array}{r}-0.219 \\
(0.746)\end{array}$ \\
\hline$\overline{\mathbf{R}}^{2}$ & 0.375 & 0.286 & 0.263 & 0.465 \\
\hline
\end{tabular}

See tables 1 and 3 for details. The individual sunk cost measures are described in Section 4.2. 


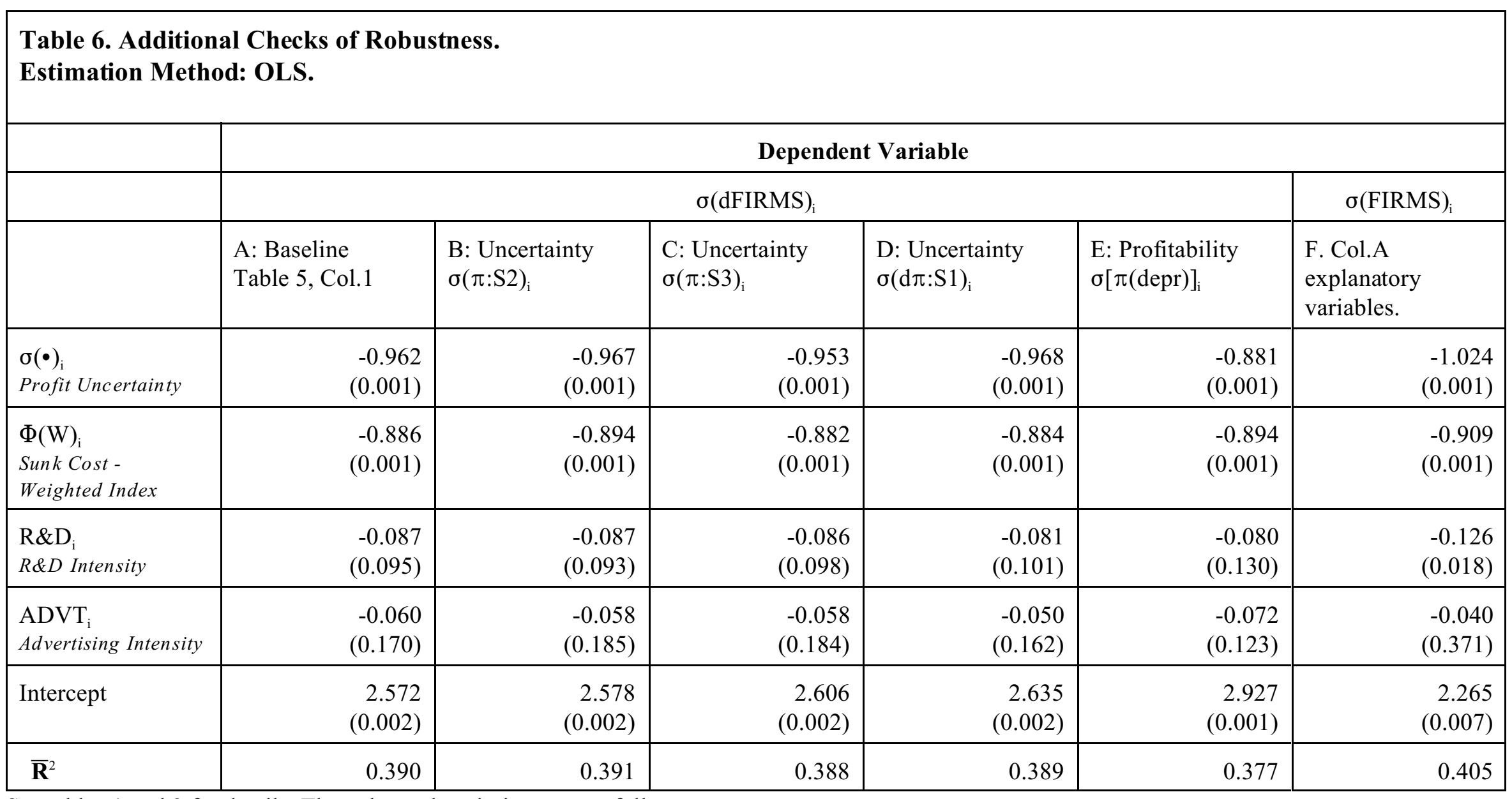

See tables 1 and 3 for details. The column descriptions are as follows.

Column A: For comparison, column 1 from Table 5 is reproduced here.

Columns B and C: Use uncertainty measures $\sigma(\pi: \mathrm{S} 2)$ and $\sigma(\pi: \mathrm{S} 3)$.

Column D: Uses detrended profits to construct the uncertainty measure.

Column E: Uses an alternate profitability measure $\pi(\mathrm{depr})$ to construct the uncertainty measure $\sigma[\pi(\mathrm{depr})]$. Forecasting equation is same as in column A. Column F: Uses the non-detrended data on the number of firms to construct the volatility measure $\sigma(\mathrm{FIRMS})_{\mathrm{i}}$. This is used as the dependent variable. The explanatory variables are same as in column A. 


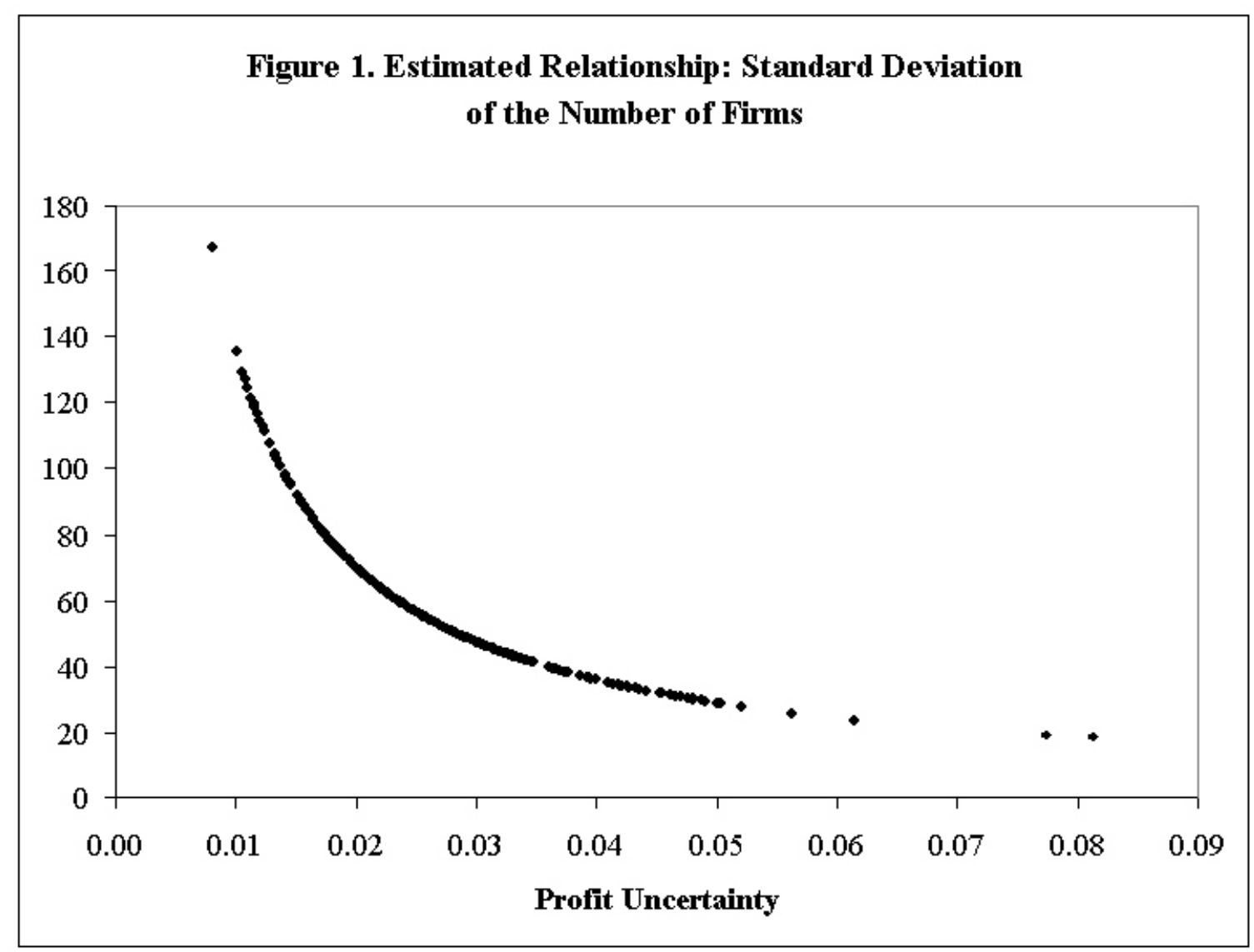




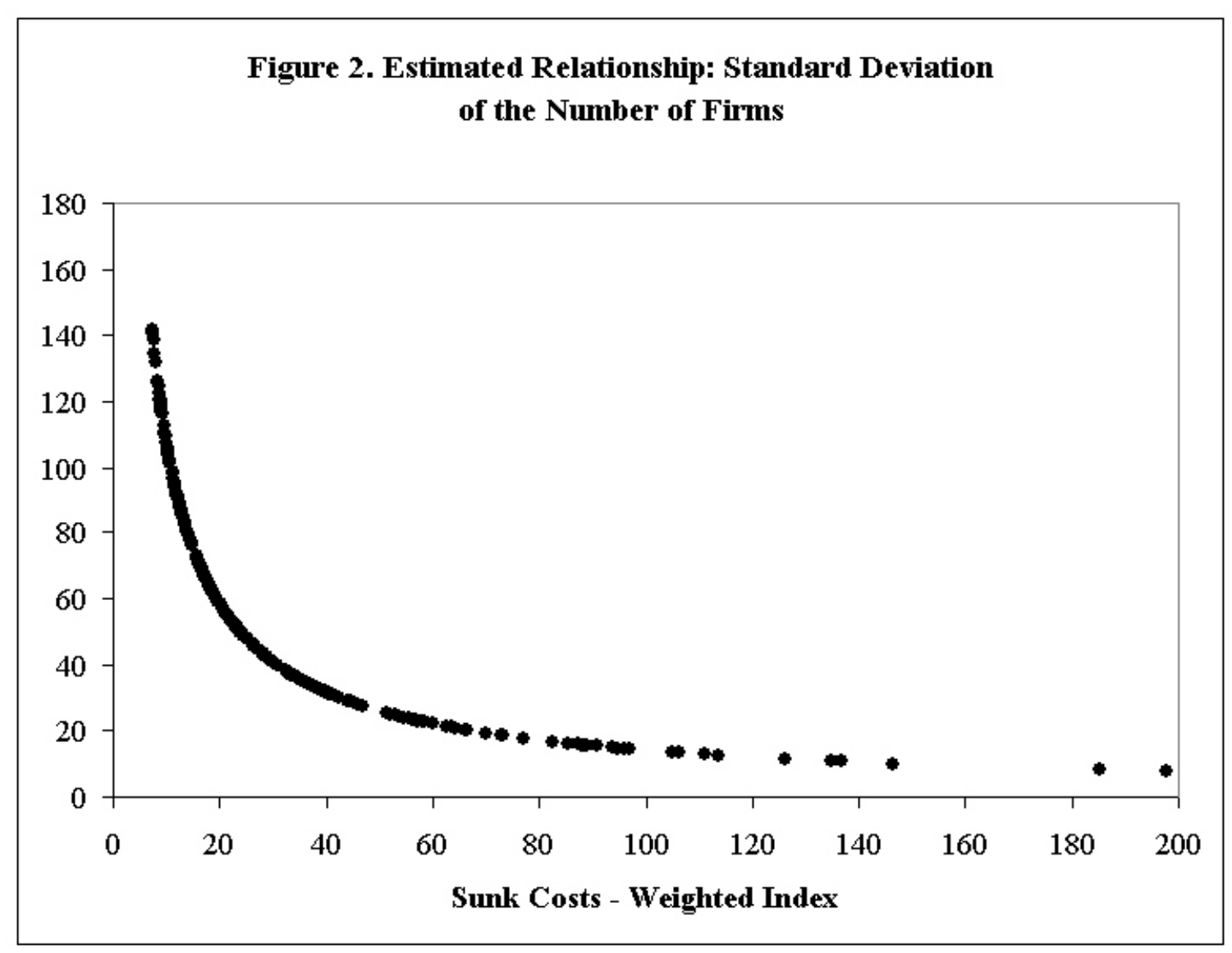


Bücher des Forschungsschwerpunkts Markt und politische Ökonomie

Books of the Research Area Markets and Political Economy

Andreas Stephan

Essays on the Contribution of Public Infrastructure to Private: Production and its Political

Economy

2002, dissertation.de

Hans Mewis

Essays on Herd Behavior and Strategic

Delegation

2001, Shaker Verlag

Andreas Moerke

Organisationslernen über Netzwerke - Die

personellen Verflechtungen von

Führungsgremien japanischer

Aktiengesellschaften

2001, Deutscher Universitäts-Verlag

Silke Neubauer

Multimarket Contact and Organizational Design

2001, Deutscher Universitäts-Verlag

Lars-Hendrik Röller, Christian Wey (Eds.)

Die Soziale Marktwirtschaft in der neuen

Weltwirtschaft, WZB Jahrbuch 2001

2001, edition sigma

Michael Tröge

Competition in Credit Markets: A Theoretic

Analysis

2001, Deutscher Universitäts-Verlag

Tobias Miarka

Financial Intermediation and Deregulation:

A Critical Analysis of Japanese Bank-Firm-

Relationships

2000, Physica-Verlag

Rita Zobel

Beschäftigungsveränderungen und organisationales Lernen in japanischen Industriengesellschaften

2000, Humboldt-Universität zu Berlin

http://dochost.rz.hu-berlin.de/dissertationen/zobel-

rita-2000-06-19

Jos Jansen

Essays on Incentives in Regulation and Innovation

2000, Tilburg University

Ralph Siebert

Innovation, Research Joint Ventures, and

Multiproduct Competition

2000, Humboldt-Universität zu Berlin

http://dochost.rz.hu-berlin.de/dissertationen/siebert-

ralph-2000-03-23/

Damien J. Neven, Lars-Hendrik Röller (Eds.)

The Political Economy of Industrial Policy in

Europe and the Member States

2000, edition sigma
Jianping Yang

Bankbeziehungen deutscher Unternehmen: Investitionsverhalten und Risikoanalyse 2000, Deutscher Universitäts-Verlag

Christoph Schenk

Cooperation between Competitors -

Subcontracting and the Influence of Information, Production and Capacity on Market Structure and Competition

1999, Humboldt-Universität zu Berlin

http://dochost.rz.hu-berlin.de/dissertationen/schenk-

christoph-1999-11-16

Horst Albach, Ulrike Görtzen, Rita Zobel (Eds.)

Information Processing as a Competitive

Advantage of Japanese Firms

1999, edition sigma

Dieter Köster

Wettbewerb in Netzproduktmärkten

1999, Deutscher Universitäts-Verlag

Christian Wey

Marktorganisation durch Standardisierung: Ein

Beitrag zur Neuen Institutionenökonomik des

Marktes

1999, edition sigma

Horst Albach, Meinolf Dierkes, Ariane Berthoin Antal, Kristina Vaillant (Hg.)

Organisationslernen - institutionelle und

kulturelle Dimensionen

WZB-Jahrbuch 1998

1998, edition sigma

Lars Bergman, Chris Doyle, Jordi Gual, Lars

Hultkrantz, Damien Neven, Lars-Hendrik Röller,

Leonard Waverman

Europe's Network Industries: Conflicting

Priorities - Telecommunications

Monitoring European Deregulation 1

1998, Centre for Economic Policy Research

Manfred Fleischer

The Inefficiency Trap

Strategy Failure in the

German Machine Tool Industry

1997, edition sigma

Christian Göseke

Information Gathering and Dissemination

The Contribution of JETRO to

Japanese Competitiveness

1997, Deutscher Universitäts-Verlag 
Fredrik Andersson

Kai A. Konrad

Lars-Hendrik Röller

Christian Wey

Talat Mahmood Klaus Schömann

Talat Mahmood Klaus Schömann

Jos Jansen

Jos Jansen

Günter Franke Harris Schlesinger Richard C. Stapleton

Tomaso Duso

Johan Lagerlöf

Paul Heidhues

Olivier Cadot Lars-Hendrik Röller Andreas Stephan

Justus Haucap

Christian Wey

Heidrun C. Hoppe Emre Ozdenoren

Rainer Nitsche

Daniel Krähmer

J. Peter Murmann

Kai A. Konrad

Robert Nuscheler

Fredrik Andersson Kai A. Konrad
Human Capital Investment and Globalization in Extortionary States

Merger Control in the New Economy

Die Determinanten der Mirgrationsentscheidung von IT-Hochschulabsolventen aus Pakistan Empirische Befunde zur Ausgestaltung der deutschen „Green Card“

The Determinants of the Migration Decision of ITgraduates from Pakistan: Empirical Evidence for the Design of a German "Green Card"

The Effects of Disclosure Regulation on Innovative Firms: Common Values

The Effects of Disclosure Regulation on Innovative Firms: Private Values

Multiplicative Background Risk

On the Politics of the Regulatory Reform:

Econometric Evidence from the OECD Countries

On the Desirability of an Efficiency Defense in

Merger Control

Contribution to Productivity or Pork Barrel? The Two Faces of Infrastructure Investment

Unionization Structures and Firms' Incentives for Productivity Enhancing Investments

Intermediation in Innovation

On the Effectiveness of Anti-Predation Rules

Entry and Experimentation in

Oligopolistic Markets for Experience Goods

The Coevolution of Industries and National Institutions: Theory and Evidence

Terrorism and the State

Physician Reimbursement, Time-Consistency and the Quality of Care

Taxation and Education Investment in the Tertiary Sector
FS IV $02-06$

FS IV $02-11$

FS IV $02-12$

FS IV $02-15$

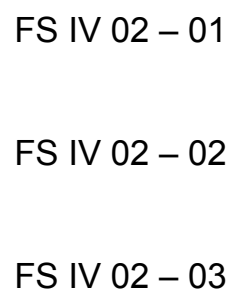

FS IV $02-02$ 
Jan Boone

Kai A. Konrad

Helmut Bester

Kai A. Konrad

Kjell Erik Lommerud Bjørn Sandvik

Odd Rune Straume

Steffen Huck Vicki Knoblauch Wieland Müller

Ralph Siebert

Jürgen Bracht

Saul Lach

Eyal Winter

Steffen Huck

Kai A. Konrad

Daniel Krähmer

Thomas Knaus

Robert Nuscheler

Kurt R. Brekke

Robert Nuscheler

Odd Rune Straume

Kai A. Konrad

Sebastian Kessing

Sebastian Kessing

Michal Grajek

Robert M. Adams Lars-Hendrik Röller

Robin C. Sickles

Tomaso Duso

Damien J. Neven Lars-Hendrik Röller

Tomaso Duso Astrid Jung
'Be nice, unless it pays to fight': A New Theory of

Price Determination with Implications for

Competition Policy

Altruism and Envy in Contests:

An Evolutionarily Stable Symbiosis

Delay in Contests

Good Jobs, Bad Jobs and Redistribution

On the Profitability of Collusion in Location Games

Learning by Doing and Multiproduction Effects over the Life Cycle: Evidence from the

Semiconductor Industry

Modeling Oligopolistic Price Adjustment in Micro

Level Panel Data

Strategic Trade Policy and the Home Bias in Firm

Ownership Structure

Delegation versus Authority

Incomplete Risk Adjustment and Adverse

Selection in the German Public Health Insurance System

Quality and Location Choices under Price

Regulation

Inverse Campaigning

A Note on the Determinants of Labour Share Movements

Employment Protection and Product Market Competition

Identification of Network Externalities in Markets for Non-Durables

Market Power in Outputs and Inputs: An Empirical Application to Banking

The Political Economy of European Merger Control: Evidence using Stock Market Data

Market Conduct and Endogenous Lobbying: Evidence from the U.S. Mobile Telecommunications Industry
FS IV $02-20$

FS IV $02-21$

FS IV $02-22$

FS IV $02-28$

FS IV $02-29$

FS IV $02-18$

FS IV $02-19$

FS IV $02-23$

FS IV $02-24$

FS IV $02-25$

FS IV $02-26$

FS IV $02-27$

FS IV $02-30$

FS IV $02-31$

FS IV $02-32$

FS IV $02-33$

FS IV $02-34$

FS IV $02-35$ 
Annette Boom

Wolfram F. Richter

Stergios Skaperdas

Johan Lagerlöf

Roman Inderst

Christian Wey

Sebastian Kessing

Robert Nuscheler

Lars Frisell

Paul Heidhues Nicolas Melissas

Pablo Beramendi

Daniel Krähmer

Ralph Siebert

Vivek Ghosal

Vivek Ghosal
Investments in Electricity Generating Capacity under Different Market Structures and with Endogenously Fixed Demand

Zur Berücksichtigung von Kindern bei umlagefinanzierter Alterssicherung

Restraining the Genuine Homo Economicus: Why the Economy cannot be divorced from its Governance

Insisting on a Non-Negative Price: Oligopoly, Uncertainty, Welfare, and Multiple Equilibria

Buyer Power and Supplier Incentives

Monopoly Pricing with Negative Network Effects: the Case of Vaccines

The Breakdown of Authority

Equilibria in a Dynamic Global Game: The Role of Cohort Effects

Political Institutions and Income Inequality: The Case of Decentralization

Self-Confidence in Contests Incumbent Firms: Market Proliferation versus Cannibalization

Impact of Uncertainty and Sunk Costs on Firm Survival and Industry Dynamics

Endemic Volatility of Firms and Establishments: Are Real Options Effects Important?
SP II $2003-05$

SP || $2003-07$

SP || $2003-10$

SP || $2003-11$

SP I| $2003-01$

SP I| 2003-02

SP || 2003-03

SP || $2003-06$

SP || $2003-08$

SP || $2003-09$

SP || $2003-12$

SP || $2003-13$ 
Bei Ihren Bestellungen von WZB-Papers schicken

Sie bitte unbedingt einen an Sie adressierten Auf-

kleber mit sowie je paper eine Briefmarke im Wert

von 0,51 Euro oder einen "Coupon Reponse Inter-

national " (für Besteller aus dem Ausland)
Please send a self addressed label and postage stamps in the amount of 0.51 Euro or a "CouponReponse International" (if you are ordering from outside Germany) for each WZB-paper requested

Absender / Return Address:

Wissenschaftszentrum Berlin

für Sozialforschung

Presse- und informationsreferat

Reichpietschufer 50

D-10785 Berlin-Tiergarten

Hiermit bestelle ich folgende(s)

Discussion paper(s):

Please send me the following Discussion paper(s):

Bestell-Nr. / Order no.

Autor/in, Kurztitel /Author(s) / Title(s) in brief 